\title{
J C Prichard's Concept of Moral Insanity- a Medical Theory of the Corruption of Human Nature
}

\author{
HANNAH FRANZISKA AUGSTEIN*
}

In the eighteenth century, insanity was widely explained within the Lockean philosophical framework of enlightened rationality: delusions or illusions, basically erroneous thinking, led human reason into the wrong. By the beginning of the nineteenth century, after the French Revolution and in the midst of the transformations which the industrial revolution brought about, new theories of insanity emerged. The realm of unsoundness changed its character and became as unfathomable as the epoch appeared to many who were witnessing it. Increasingly, cases of insanity became known where the patients did not seem to dwell in some delusive state. They displayed deep sullenness, unmitigated fury, utter shamelessness, seemingly without either purpose or motivation.

One of the constructs newly used to explain the evidence was the concept of moral insanity. It referred to a derangement of those mental faculties which presided over man's emotive framework as well as his moral faculty. It was formulated by the Bristol doctor James Cowles Prichard (1786-1848), who put it forward first in 1833, in an article in The cyclopaedia of practical medicine. ${ }^{1}$ In the Treatise on insanity, published in 1835, he gave his account of medical knowledge on madness, ${ }^{2}$ inscribing moral insanity into medical nosology and embedding the doctrine in his medical philosophy. In the course of his elaborations of the concept, Prichard presented a number of case studies which he had solicited from other doctors in order to prove his theory. One of these was the case of "a gentleman" provided by his Bristol colleague, John Addington Symonds, who reported that:

In his social relations [the gentleman] had become fickle, suspicious, and irascible; he was reckless in his expenditure, and uncertain in his projects, while his general behaviour was such as to impress almost every one who came in contact with him. [However, there was no] evidence that he entertained any belief in things morally or physically impossible, or in opposition to the general opinion of mankind. ... [ [He] had suffered a severe concussion of the brain, and since his recovery had conducted himself more extravagantly than ever. He advertised for sale property which he knew to be entailed; after a little increase of income by the death of a near relative, he commenced great

*Hannah F Augstein, Wellcome Institute for the History of Medicine, 183 Euston Road, London NW1 2BE.

I should like to thank W F Bynum, Christopher Lawrence, Michael Neve and Roy Porter for their good advice and criticism. I am also much indebted to Vivian Nutton and Caroline Tonson-Rye for their editorial expertise.

Unless otherwise stated, all translations from German and French sources are mine.

\footnotetext{
1 James Cowles Prichard, 'Insanity', in J Forbes, A Tweedie, J Conolly (eds), The cyclopaedia of practical medicine, 4 vols, London, Sherwood, Gilbert, Piper, 1833-35, vol. 2, pp. 10-32, 847-75.

2 James Cowles Prichard, A treatise on insanity, and other disorders affecting the mind, London, Sherwood, Gilbert, and Piper, 1835.
} 


\section{Hannah F Augstein}

alterations in his residence, and before they were finished suddenly left his family, together with a large establishment, under the care of a youth, his son, who was provided with no other means of supplying the wants of the household than a power of attorney for collecting rents. [The man had inflicted] so great injury to property in which he had only a life-interest, had involved himself so deeply in debt, and was, notwithstanding, so lavish and absurd in his expenditure, that it became a very desirable object to enforce some restraint upon his actions.

"After due deliberation", Symonds ended, "I came to the conclusion, that, although I had been unable to trace any positive intellectual error, there was such a morbid condition of the feelings, habits, and motives, as to constitute a case of what has been correctly designated by Dr. Prichard as moral insanity. I therefore did not hesitate to sign the usual certificate". 3

The communications by Symonds and other alienists seemed to confirm the theory of moral insanity. ${ }^{4}$ Prichard had defined it as a form of

madness consisting in a morbid perversion of the natural feelings, affections, inclinations, temper, habits, moral dispositions, and natural impulses, without any remarkable disorder or defect of the intellect or knowing and reasoning faculties, and particularly without any insane illusion or hallucination.

People suffering from this mental disorder displayed, Prichard wrote, "eccentricity of conduct, singular and absurd habits" combined with "a wayward and intractable temper, with a decay of social affections, an aversion to the nearest relatives and friends formerly beloved,-in short, with a change in the moral character of the individual". 5

Neither the sources of the concept nor its social and philosophical implications have been described conclusively. It has been variously suggested that moral insanity linked up with later notions concerning "lesions of the will power", 6 or that the concept derived from tenets of Scottish Enlightenment philosophy, or from the French alienists Philippe Pinel and Jean Etienne Dominique Esquirol. ${ }^{7}$ But most of those scholars who put forward these theories were merely cursorily interested in Prichard. His theories on madness rarely stood at the centre of investigation. ${ }^{8}$

${ }^{3}$ Ibid., pp. 48-50.

${ }^{4}$ Prichard collected his cases where he could find them. He used material sent to him by his colleagues, excerpts from medical literature and personal experience. An analysis of his cases would certainly be interesting. This, as well as many other issues which I can only hint at here, is more fully addressed in my forthcoming $\mathrm{PhD}$ thesis on Prichard (University College London).

${ }^{5}$ Prichard, op. cit., note 2 above, pp. 6, 23-4. In 1840 , he enumerated ten salient features of moral insanity; they include " a state of excitement ... alternate with corresponding depression", "the propensity to make extravagant purchases", "garrulity", to "melancholy", see Prichard, 'Insanity', in Alexander Tweedie (ed.), The library of medicine, London, Whittaker, 8 vols, $1840-42$, vol. 2, pp. 112-13 (Prichard's emphases).

6 See Eric T Carlson and Norman Dain, 'The meaning of moral insanity', Bull. Hist. Med., 1962, 36: 130-40, on pp. 137-9; Joel Peter Eigen, Witnessing insanity: madness and mad-doctors in the English court, New Haven, Yale University Press,
1995, pp. 77-9. Roger Smith regards Maudsley's theories on the influence of heredity on insanity as a repetition of Prichardian tenets (see Roger Smith, Trial by medicine: insanity and responsibility in Victorian trials, Edinburgh University Press, 1981, on p. 54); so does H Werlinder, Psychopathy: $a$ history of the concepts; analysis of the origin and development of a family of concepts in psychopathology, Stockholm, Almqvist \& Wiksell, 1978 , p. 48.

${ }^{7}$ Carlson and Dain, op. cit., note 6 above, p. 134; Eigen, op. cit., note 6 above, p. 77. Walker and McCabe maintained that Prichard "was simply importing the view of Pinel and Esquirol", see Nigel Walker and Sarah McCabe, Crime and insanity in England, 2 vols, Edinburgh University Press, 1973, vol. 2, p. 208.

${ }^{8}$ Apart from Carlson and Dain, Walker and McCabe, Prichard's moral insanity has been dealt with mainly by nineteenth-century authors. See J C Bucknill, D Hack Tuke, A manual of psychological medicine, London, Churchill, 1858, pp. 101-20; D H Tuke, Prichard and Symonds in especial relation to 


\section{J C Prichard's Concept of Moral Insanity}

This article proposes to look at two issues: first, it will probe the theoretical predicaments which inspired Prichard to come up with the concept of moral insanity, and in the course of this Prichard's previously neglected sources will be examined. Second, the paper will also discuss the concept of moral insanity itself and enquire into its underlying implications as well as into the functions which it fulfilled within Prichard's political and religious viewpoints. In particular, I will ask how far "moral insanity" was an expression of Prichard's religious views and to what extent it was presented as a response to the rise of capitalist society.

In the contemporary historiography of madness, there is a strong urge to unmask the economic or professional interests which informed the medical theories of nineteenthcentury alienists. Scholars such as Andrew Scull, David Mellett, and Richard Russell have helped to put the history of madness into perspective. ${ }^{9}$ At first sight, the case described above may appear as evidence of Prichard's desire to enlarge the juridical competencies of his profession. But a closer look reveals that his work allows this kind of analysis to only a very limited extent. To read his writings in this light would be to mistake the actual non-medical sub-text of his theories. Since this paper involves many different components it may be useful to give a short outline of what it proposes to do. By retracing Prichard's route to moral insanity, I wish to demonstrate that the theory reflected Prichard's dismay at the decline of religion in a materialist age. Yet, the concept of moral insanity was not merely the disillusioned response of a cultural pessimist to everything he disliked about his epoch. By explaining madness within the framework of humoralism as a bodily constitution, Prichard dispensed with the idea that reason was the supreme arbiter of humanity. He showed madness to be part of the human condition: anybody was liable to become mad. The descent into madness proper was the result of accidental circumstances. By virtue of this theory Prichard defied the pretensions of the phrenologists who claimed to have found a key to the human psyche. In his anti-phrenological approach, based on non-cerebral sources of madness, Prichard was heavily inspired by German Romantic medicine. However, it was only in the 1840 s that he finally acknowledged the intimate links between German teachings and his theory of moral insanity. How little Prichard shared contemporary attempts to bolster the image of the medical profession, how little, indeed, he believed that medicine could do anything about the depraved state of human nature, is revealed in his answer to the question under what circumstances it was necessary to certify a mentally disturbed person.

\footnotetext{
mental science with chapters on moral insanity, London, Churchill, 1891, pp. 65-100; Denis Leigh, 'James Cowles Prichard, M.D., F.R.S. 1786-1848' in idem, The historical development of British psychiatry, Oxford, Pergamon, 1961. See also F A Whitlock, 'Prichard and the concept of moral insanity', Aust. N.Z. J. Psychiatry, 1967, 1: 72-9.

${ }^{9} \mathrm{D} J$ Mellett, The prerogative of asylumdom, New York, Garland, 1982; Richard Russell, 'Mental
}

physicians and their patients: psychological medicine in the English pauper lunatic asylums of the later nineteenth century' PhD thesis, Sheffield University, 1983; Andrew Scull, Social order/mental disorder: Anglo-American psychiatry in historical perspective, London, Routledge, 1989; idem, The most solitary of afflictions: madness and society in Britain, 1700-1900, New Haven, Yale University Press, 1993. 


\section{Hannah F Augstein}

\section{Definitions of Moral Insanity}

The term "moral insanity" had already been employed in the eighteenth century by Thomas Arnold and Benjamin Rush. But they saw the perversion of the moral sense as a result of madness - not as the definition of the disorder. Their ideas, therefore, had little to do with Prichard's understanding of the term. ${ }^{10}$ Prichard himself saw parallels between the notion of moral insanity and the theory of Jean Etienne Dominique Esquirol (1772-1840), the famous Paris mad-doctor. ${ }^{11}$ Prichard even averred that Esquirol had identified the salient characteristic of moral insanity-the absence of intellectual delusion. ${ }^{12} \mathrm{He}$ was justified in so far as Esquirol had introduced "the view that the obsessional disorders were a form of insanity". ${ }^{13}$ Ironically, however, the French alienist dissociated himself explicitly from Prichard's definition of moral insanity, for Esquirol insisted that all forms of madness were accompanied by a lesion of the understanding. ${ }^{14}$ Only after Esquirol's death in 1840 would Prichard no longer refer "moral insanity" to the French doctor's concept of "monomania". In 1842 he wrote: "With great deference to this justly celebrated physician we venture to observe that the term monomania does not appear applicable to a disorder which is not characterised by any particular error or delusion". ${ }^{15}$ But there are other authors whom Prichard read and quoted and whom, in his Treatise on insanity, he did not credit with having inspired him.

Prichard was a very pious man. Born in Ross, Herefordshire, in 1786, he was brought up in Bristol as a Quaker. Even though, in 1810, he converted to Anglicanism, he never forsook stern religious concern and a literal belief in Scripture's tenets which became increasingly rare among his fellow-scientists. Prichard's father was a merchant with a penchant for erudition, so his son was given the opportunity to study medicine in Edinburgh where he became familiar with the doctrines of Scottish Enlightenment philosophy and medical theory. Subsequently he became a doctor in Bristol where he treated pauper lunatics as well as more affluent patients. Throughout his life, Prichard's energies were divided between the medical profession and his investigations into anthropology and philology. His anthropology was transcendental and deeply teleological: he was interested in moral redemption, intellectual and cultural perfection. He saw man in the light of final causes and was not concerned with the tedious fetters of physical circumstances which prevented him from fulfilling his rational and moral potential. A resumé of Prichard's scholarly endeavours-anthropological as well as physiologicalcan be made in four words: to save man's soul.

\footnotetext{
${ }^{10}$ Thomas Arnold, Observations on the nature, kinds, causes and prevention of insanity, 2 vols, London, Phillips, 1806, vol. 1, p. iv. For Benjamin Rush see Richard Hunter, Ida Macalpine, Three hundred years of psychiatry, 1535-1860, Hartsdale, Carlisle Publ., 1982, p. 665.

${ }^{11}$ For Esquirol see Jan Goldstein, Console and classify: the French psychiatric profession in the nineteenth century, Cambridge University Press, 1987, passim; G Swain, Le Sujet de la folie, Toulouse, Privat, 1977.

12 Prichard, op. cit., note 2 above, p. 15. In 1831, Prichard paid a visit to Esquirol at his hospital at Ivry
}

near Paris (Prichard's article on 'Temperaments', in op. cit., note 1 above, vol. 4, p. 172).

${ }^{13} \mathrm{G}$ E Berrios, 'Obsessional disorders during the nineteenth century: terminological and classificatory issues', in W F Bynum, Roy Porter, Michael Shepherd (eds), The anatomy of madness, 3 vols, vols 1 and 2: London, Tavistock; vol. 3: London, Routledge, 1985-88, vol. 1, p. 170.

14 J E D Esquirol, 'Monomanie', in idem, Des maladies mentales considérées sous les rapports médical, hygiénique et médico-légal, 2 vols, Paris, J B Baillière, 1838, vol. 2, p. 5.

${ }^{15}$ Prichard; op. cit., note 5 above, p. 114. 


\section{J C Prichard's Concept of Moral Insanity}

Prichard voted Tory. He adhered to notions of paternalism that he considered to be under threat from political radicalism and economic utilitarianism. His cosmos was thoroughly divided. There was the religious sphere which was horizontally organized, all men being equal in the eyes of God; and there was the world of men which was vertically structured, consisting of hierarchies whose existence-as the French Revolution had proved-was vital for political coherence as well as the persistence of religion. ${ }^{16}$

This short profile of Prichard appears at odds with his formulation of a theory like that of moral insanity which smacked of novelty and whose nosology, as will be explained, came dangerously close to the tenets of F J V Broussais who was derided as a materialist. That Prichard should have devised such a theory is all the more surprising since certain aspects of it seemingly contradicted his own earlier work. In 1822, he had published a Treatise on diseases of the nervous system, in many respects a conventional account of insanity, devised along the lines of the Lockean notion that a madman had lost his wits, but not his soul. ${ }^{17}$ It fulfilled two purposes. First, Prichard used it to refute the popular, non-medical idea that the soul or mind itself could be diseased. Second, he employed it to defend religion against materialists who located madness in the brain and reduced the soul to a function of the brain. Against both of these notions Prichard pitted the idea that insanity consisted in a faulty transmission of data from the brain into the mind. Madness, in other words, arose from some organic malfunctioning either in the brain or in the nervous system more generally. The brain was not the organ of mind but the intermediary between the body and the immaterial reasoning powers. How the brain related to the reasoning faculty, Prichard thought to be a medical mystery which man was not given to penetrate. ${ }^{18}$ All he knew for sure was that madness was seated in the nervous system, whereas the mind was "in no wise involved in the calamity". ${ }^{19}$ But owing to some mechanico-chemical disorder in the nervous system the mind was led to take for "memory" what in fact was merely "reverie", so that its reasoning operations subsequently went amiss. ${ }^{20}$ By putting forward this explanation, Prichard saw himself as following in the tradition of William Cullen, a teacher of James Gregory whose courses on medical practice Prichard had attended at Edinburgh. ${ }^{21}$ Indeed, the highest medical authorities had

\footnotetext{
${ }^{16}$ For Prichard's biography see the entry under his name in Charles Coulston Gillispie (ed.), Dictionary of scientific biography, New York, Charles Scribner's Sons, 16 vols, 1970-1980, vol. 11, pp. 136-8; George W Stocking Jr, 'From chronology to ethnology: James Cowles Prichard and British anthropology, 1800-1850', in J C Prichard, Researches into the physical history of man, ed. G W Stocking, University of Chicago Press, 1973; John Addington Symonds, Some account of the life, writings, and character of the late James Cowles Prichard, Bristol, Evans \& Abbott, 1849; G E Weare, James Cowles Prichard (physician and ethnologist, 1781 [sic]-1848). A brief retrospect, reprinted from Bristol Times and Mirror, 1898.

17 John Locke, An essay concerning human understanding, ed. John Yolton, London, Everyman, 1961, bk. II, p. xxxiii. For the prevalence of the Lockean definition in the eighteenth century see Roy Porter, Mind-forg'd manacles: a history of madness
}

in England from the Restoration to the Regency, London, Penguin Books, 1990.

$18 \mathrm{~J}$ C Prichard, A treatise on diseases of the nervous system: part the first, comprising convulsive and maniacal affections, London, Thomas and George Underwood, 1822, pp. 42-3. (The fact that the second volume never appeared is indicative of Prichard's changed attitudes towards insanity.)

${ }^{19}$ Ibid., p. 119 (Prichard's emphasis). Following common-sense philosophy, Prichard divided the mental faculties into judgement and reasoning on the one hand and the passions, appetites, propensities, and volition on the other hand. Pages $1-40$ of his treatise are devoted to proving why these innate mental faculties can be affected by disorders of the nervous system such as madness only in so far as the bodily framework is instrumentally important for the operation of the mind.

${ }^{20}$ Ibid., pp. 37-8, 128-32.

21 Ibid., p. 128. 


\section{Hannah F Augstein}

sanctioned the doctrine. The Tukes had used it as the basis of their maxims on moral treatment. ${ }^{22}$ It was the standard definition in British legal practice. ${ }^{23}$ There was no obvious reason for Prichard to give it up.

None the less, in the mid-thirties, we find him stating in $A$ treatise on insanity that the traditional account of madness was not sufficient; Locke's theory was "by far too limited". The formula "reasoning correctly from erroneous premises" was applicable to certain forms of insanity only, namely to all those in which the understanding was out of order. But there existed another type of madness to which Locke's definition did not apply. ${ }^{24}$ It consisted in the perversion of the emotive faculties, such as the sense of self-preservation or natural affection for one's relatives. In 1822, Prichard had stipulated that these, together with the reasoning power, were beyond physical illness since they were innate attributes of the immaterial mind. In 1835, they were still faculties of the mind of an immaterial nature, but, Prichard declared, they could be diseased. ${ }^{25}$ Materialistic as that sounds, Prichard was far from resigning himself to physicalism. Why then, it must be asked, did Prichard depart from received medical doctrines?

\section{Prichard's Opposition to Materialist Philosophy}

My suggestion is that both the 1822 and the 1835 treatises had the same target. They were attempts by Prichard to attack materialistic physiology, most notably phrenology. Craniology -as it was also called-was, for him, something akin to the application of Priestley's materialism to the philosophy of mind. ${ }^{26}$ Between 1810 and 1819, Franz Joseph Gall and Johann Caspar Spurzheim had published five big volumes on the anatomy and functions of the brain. ${ }^{27}$ In this multi-volume insult to Prichard's world view, Gall and Spurzheim divided the brain into numerous distinct "organs", each of which was responsible for a particular mental faculty. The respective size of these organs was visible from the outside: the skull displayed protuberances in those places where certain faculties were especially well developed. The soul, in other words, had its place in the brain. ${ }^{28}$ The innermost nature of man was evident to everybody who only knew how to read the signs,

22 Cf. Roy Porter, op. cit, note 17 above, pp. 192, 276. As to the survival of Locke's theory in general see chs 2 and 4.

${ }^{23} \mathrm{Cf}$. German E Berrios, 'Delusions as "wrong beliefs": a conceptual history', Br. J. Psychiatry, suppl. 14, 1991, 159: 6-13, on pp. 7, 9. According to Roger Smith, the juridical definition for insanity did not change from the eighteenth to the nineteenth century, see Smith, op. cit., note 6 above, pp. 14-15.

24 Prichard, op. cit., note 2 above, pp. 3-4.

25 Ibid., pp. 6, 11. Prichard talks about "disordered" or "disturbed" faculties.

26 Idem, op. cit., note 18 above, pp. 50-5.

${ }^{27}$ Franz Joseph Gall, Gaspar [sic] Spurzheim, Anatomie et physiologie du système nerveux en général, et du cerveau en particulier, avec des observations sur la possibilité de reconnoître plusieurs dispositions intellectuelles et morales de l'homme et des animaux, par la configuration de leurs têtes, 5 vols, Paris, printed by F Schoell for the
Bibliothèque Grècque-Latine-Allemande, 1810-19 (vols 1 and 2 were written jointly by Gall and Spurzheim, the remaining vols were published solely under Gall's name).

${ }^{28}$ Notions of the soul and the mind were not entirely congruent. But when it came to criticizing the phrenologists and other anatomists' endeavours to locate the soul within parts of the brain, the critics did not neatly distinguish between the two. OehlerKlein has emphasized that Gall tried to eschew the materialist epitheton; see Sigrid Oehler-Klein, Die Schädellehre Franz Joseph Galls in Literatur und Kritik des 19. Jahrhunderts, Soemmerring Forschungen, Bd. 8, Stuttgart, Gustav Fischer, 1990, pp. 106-14. For the varying treatments of the mind and the soul see Edwin Clarke and L S Jacyna, Nineteenth-century origins of neuroscientific concepts, Berkeley, University of California Press, 1987. 


\section{J C Prichard's Concept of Moral Insanity}

i.e. the bumps. Throughout his life Prichard railed against this theory, ${ }^{29}$ but over time he was to change his arguments.

At Edinburgh University, Prichard had become acquainted with the common-sense philosophy of Dugald Stewart and Thomas Reid. Its tenets were readily reconcilable with Christian theology. Diametrically opposed to these doctrines and yet structurally very similar were the ideas of Gall and Spurzheim. Both systems presupposed certain innate faculties: a moral sense, natural affections, the power of understanding, etc. But while the common-sense philosophers referred these to the immaterial mind, the phrenologists, in locating them in the brain, underlined their material nature. This notion was tied to Gall's inference "that the moral and intellectual world of man begins where the brain begins, and that it ends where the brain ends". This theory appeared to Prichard all the more pernicious as Gall doubted the perfectibility of human morals. If people could fall back into ignorance and barbarism, this was, for Gall, due to the physical limits which their brains posed to the development of the moral faculties. ${ }^{30}$

Prichard's Treatise on diseases of the nervous system aimed at refuting the central tenets of phrenology, including what he perceived as a debasement of humanity. He strove to show (1) that the supreme faculties of the mind were independent of the bodily constitution; $;^{31}(2)$ that for the exercise of the lower faculties of perception and sensation (i.e. those which could be perturbed) the entire nervous system was at least as important as the brain itself; ${ }^{32}$ and (3) that some forms of madness, such as epilepsy, were-“in some unknown way"-ultimately referable to an "irritated portion of the stomach or intestines" or "disease in the liver, and other abdominal viscera"-and therefore not to some lesion of the cerebral structure. ${ }^{33}$ His tactic was to discount the role of the brain alone, playing down its significance for mental processes, whether in sickness or in health. It was an approach which Prichard never forsook. The problem was, however, that the main hypothesis of the 1822 book could not be sustained. It became increasingly impossible to assert that mental processes were independent of the particular conformation of the brain, for, during the $1820 \mathrm{~s}$, a rising number of pathological anatomists attributed insanity to lesions of specific parts of the brain. The results of experimental physiologists, who manipulated the brain structures in animals, made it more and more difficult to deny that mental functions were dependent on the cerebral structure. $^{34}$

\footnotetext{
${ }^{29}$ Prichard's anti-phrenological stance has been pointed out by William F Bynum, 'Time's Noblest Offspring: the problem of man in the British natural historical sciences, 1800-1863', PhD thesis, University of Cambridge, 1974, pp. 215-22. See also Roger Cooter, The cultural meaning of popular science: phrenology and the organization of consent in nineteenth-century Britain, Cambridge University Press, 1984, pp. 46, 377 (n. 4).

${ }^{30}$ Gall and Spurzheim, op. cit., note 27 above, vol. 4 (1818), p. 256.

31 See note 19 above.

32 Prichard, op. cit., note 18 above, p. 13. Prichard wrote: ". . . whether the brain is allowed, or not, to
}

\begin{abstract}
be the organ of sensation and perception, no physiologist has yet contended, or will ever, I presume, venture to dispute, that some portion of the nervous system is instrumental to these operations".

${ }^{33}$ Ibid., pp. 242, 323.

34 For the development of neurological anatomy see W F Bynum, 'Varieties of Cartesian experience in early nineteenth-century neurophysiology', in S F Spicker, H T Engelhardt, Jr (eds), Philosophical dimensions of the neuro-medical sciences, Dordrecht, D Reidel, 1976; see also Clarke and Jacyna, op. cit., note 28 above. For the French context Goldstein is excellent, op. cit., note 11 above.
\end{abstract}




\section{Hannah F Augstein}

The question which engaged many mad-doctors was whether insanity was regularly accompanied by a physical lesion of the brain. Until 1820, it was commonly assumed that in many cases of madness, there were no lesions to be discovered. Implicitly, this view bolstered the notion that the brain was not the organ of mind. But in the 1820s the tide changed, the "seekers after the "sick organs" gained in confidence. Especially among French medical men, lack of pathological evidence was taken as a proof of the immaturity of pathological techniques rather than as a fact. ${ }^{35}$ Prichard considered the writings of Esquirol's protégé Etienne-Jean Georget as decisive. Georget asserted that insanity was an idiopathic disease of the cerebral structure. His publication on insanity in $1823^{36}$ inspired, as Prichard put it, "minute and laborious researches into the morbid changes connected with this disease". ${ }^{37}$ But Georget held many tenets which Prichard scorned. He was a fervent adherent of Gall's craniology, he was regarded as the spearhead of French liberal medical theory, and he "openly professed materialism". ${ }^{38}$ But since his opinions were accepted within the influential Esquirol circle, Prichard had to come to terms with the new emphasis on pathological and anatomical evidence. Even under the tutelage of the conservative Esquirol, ${ }^{39}$ French physiology and anatomy were permeated by views which, in England, were likely to be seen as verging on materialism. Esquirol himself denounced the "rash pretensions of those who assume that they can fix upon the diseased portion of the brain". ${ }^{40}$ But this did not prevent his pupils from pursuing the path which Gall and Spurzheim had delineated. If only some of their findings were true, then what happened to the mind? What was left of the inviolable soul, the divine spirit in man?

\section{The Temptations of German Romanticism}

In the $1820 \mathrm{~s}$, in the course of contemplating the nature of madness and the make-up of the mental faculties, Prichard came across a medical approach which spelled out many of his own implicit assumptions about the cultural meaning of madness and which helped him to come to terms with the notion that mental faculties could be diseased like any other part of the body. It was a form of somatic pathology which would not-like that of Gallregard the functions of the soul as congruent with the structure of the brain. It relieved Prichard of the problem of how to reconcile medicine with metaphysics. The crucial belief was a form of emotional insanity which was by definition not accompanied by a lesion of the cerebral structure. The notion came from Germany, from what Prichard referred to as "the school of Nasse". ${ }^{41}$ The doctrines of this group were derived from the Idealist philosophy of mind. Unlike the theory of "mania without delusion" which Philippe Pinel (1746-1826) had applied to raving maniacs who, before and after their fits, displayed no

\footnotetext{
${ }^{35}$ Goldstein, op. cit., note 11 above, p. 253.

${ }^{36}$ Etienne-Jean Georget, De la folie ou aliénation mentale, Paris, Rignoux, 1823.

${ }^{37}$ Prichard, op. cit., note 2 above, p. 214.

38 The quote is from Georget himself, cited in Goldstein, op. cit., note 11 above, p. 256. According to Goldstein the influence of Gall "was pervasive" among the members of the Esquirol circle, ibid., pp. 179-80, 256. As for Georget's phrenological stance see Georget, op. cit., note 36 above, p. 47.
}

\footnotetext{
${ }^{39}$ Dörner has given a lucid description of the relation between Esquirol's social background and his theory. Klaus Dörner, Bürger und Irre, Frankfurt, Syndikat/EVA, 1984, 2nd rev. ed., pp. 153-67.

40 Prichard, op. cit., note 2 above, p. 213, (his translation).

${ }^{41}$ Idem, 'Observations on the connexions of insanity with diseases in the organs of physical life', Prov. med. surg. J., 1844, 7: 323-4, on p. 323.
} 


\section{J C Prichard's Concept of Moral Insanity}

delusive convictions, ${ }^{42}$ that of the Nasse school addressed a wider range of emotional disorders that comprised not only states of "exalted mania", but all possible sorts of emotional aberration, ranged on a scale from excess to depression. It was to become the core of moral insanity.

From the last third of the eighteenth century, the Germans had been debating the relationship between body and soul, with respect to anthropology as well as to physics. ${ }^{43}$ By the 1820s there were two opposing factions who quarrelled passionately with each other: the somatists of the Nasse school, and the psychicists under the theoretical guidance of Johann Christian August Heinroth (1773-1843). German medical theory, unlike French, was slow to enter Britain. ${ }^{44}$ When the English finally got round to reading the Germans, they picked out what they needed, irrespective of whether they were combining notions which in Germany belonged to separate schools. In this, Prichard was no exception, and his sympathy for certain parts of Heinroth's doctrines did not prevent him from cherishing tenets of the Nasse school as well.

It is well known that conservative British men of letters such as Carlyle and Coleridge found in German Romanticism the depth of religiosity and feeling which they felt was lacking in their own culture. Prichard too turned to German learning and German piety. His scientific ethos required him to express his theories without having recourse to theological arguments. It was an attitude which applied not only to his ideas on madness but also to his anthropological and philological writings. ${ }^{45}$ None the less, he had great sympathy for scholarly texts whose authors were less conscious about the conflation of theology and science. In this respect, German Romantic medical theories served as a legitimation of his own opinions.

Christian Friedrich Nasse, Maximilian Jacobi, Franz Francke and a few other Germans had as their mouthpiece a periodical edited by Nasse, initially called Zeitschrift für psychische Ärzte, later on Zeitschrift für Anthropologie. Published in Leipzig from 1818, it was reckoned the first high-quality periodical on insanity to be set up in Germany. ${ }^{46}$ In 1824, the journal included an excerpt from Prichard's book on nervous disorders. ${ }^{47}$ It was

\footnotetext{
42 Philippe Pinel, A treatise on insanity, trans. D D Davis, Sheffield, Cadell and Davies, 1806.

${ }^{43}$ As to the usage of anthropology in the life sciences of the eighteenth and nineteenth centuries see Mareta Linden, Untersuchungen zum Anthropologiebegriff des 18. Jahrhunderts, Bern, Herbert Lang, 1976. For accounts of German psychiatry see Erwin Ackerknecht, Kurze Geschichte der Psychiatrie, 3rd improved ed., Stuttgart, Enke, 1985; Dörner, op. cit., note 39 above. A concise overview as well as further references to monographs on German psychiatry are to be found in Otto M Marx, 'The beginning of psychiatric historiography in nineteenth-century Germany', in Mark S Micale, Roy Porter (eds), Discovering the history of psychiatry, New York, Oxford University Press, 1994. For German therapeutics see idem, 'German Romantic psychiatry: Part 1', Hist. Psychiatry, 1990, 1: 351-80; idem, 'German Romantic psychiatry: Part 2', ibid., 1991, 2: 1-26; Gerlof Verwey, Psychiatry in an anthropological and biomedical context: philosophical
}

presuppositions and implications of German psychiatry, 1820-1870, Dordrecht, D Reidel, 1984.

${ }^{44}$ Hunter and Macalpine, op. cit., note 10 above, p. 1014.

${ }^{45}$ For a more extensive treatment of this subject see my PhD thesis: 'James C. Pritchard's views of man. An anthopologist between the Enlightenment and the Victorian age', University of London, 1996.

46 The American alienist Pliny Earle saw it as the first German journal on insanity of some standing. "The influence of the Journal was", as Earle put it, "favourable to the cause of the insane, as it" inter alia "awakened in its readers ... an interest in the improvement of hospitals"; see Pliny Earle, Institutions for the insane in Prussia, Austria and Germany, New York, Wood, 1854, pp. 5-16, 19-26, 28-9, quote from Hunter and Macalpine, op. cit., note 10 above, p. 1015 .

${ }^{47}$ Prichard, 'Beobachtungen über die Beziehung des Gedächtnisses zum Gehirn', Zeitschrift für die Anthropologie, 1824, 7: 243-50. 
then, at the latest, that he became acquainted with these particular German theories of madness. Indeed, Prichard's footnotes in his 1835 Treatise on insanity reveal that he paid a lot of attention to the Zeitschrift and the articles of one of its most eminent editors, Maximilian Jacobi. ${ }^{48}$

Deeply involved in Romantic philosophizing, the contributors of the Zeitschrift tried to defend what they perceived as real and inner human values against superficial French rationality. Practising in Halle and Bonn, Nasse (1778-1851) was a pupil of Johann Christian Reil. ${ }^{49}$ Jacobi (1755-1858) was the son of a famous philosopher who had been a companion of Goethe. ${ }^{50}$ Their politics of the body bolstered the notion of a holistic interplay between all parts of the body and the soul, while at the same time, they believed in a distinct hierarchy in which the soul was constantly at odds with the flesh. When the body took over, the state of health as well as the morality of the individual was in danger. Nasse, Jacobi, and a Dresden doctor called Franz Francke (1796-1837) propounded the idea that there existed a form of mental dislocation which was caused by diseases of the visceral organs and which expressed itself solely in a derangement of the emotions. Starting from the position of Cartesian dualism, turning himself against Stahl's animism and Heinroth's exuberant idealism as well as the psychical materialism which many zealous anatomists proposed, ${ }^{51}$ Francke asserted, in 1824, what Prichard had suggested two years earlier, namely that madness was "a sympathetic disease of the brain" whose original source was an organic disease in the viscera. He said, "The essence, the natural cause of psychical disease resides in the body",52 and expressly turned against those pathologists for whom anatomical evidence of brain disorder was a guide to the seat and nature of the disease. ${ }^{53}$ Nasse mocked "the doctrine, repeated in all physiological textbooks, that the soul must have a distinct seat somewhere in the body". He saw the entire living body as a unity, and hence madness affected the whole of man's physical appearance. ${ }^{54}$ It may be, Jacobi wrote, that the manifestations of the reasoning faculty are almost fully intact, and "none the less there is mental disturbance". For, "this or that side of the emotional life may be affected" by some disease of "certain parts of the organism".55 These views are so nearly allied to the theory of moral insanity that it appears quite likely that the German texts left their trace in Prichard's mind.

\footnotetext{
48 Prichard, op. cit., note 2 above, pp. 32, 116-17, $138,169,178,184,194-98,237-42,248$.

${ }^{49}$ For biographical details of Nasse see Werner von Noorden, Der Kliniker Christian Friedrich Nasse 1778-1851, Jena, G Fischer, 1929.

50 For Jacobi's theory see Dörner, op. cit., note 39 above, pp. $270 \mathrm{ff}$; Verwey, op. cit., note 43 above, pp. 27-30. Biographical data can be found in the otherwise totally unacceptable work by Johannes Herting, Carl Wigand Maximilian Jacobi, ein deutscher Arzt (1755-1858): Ein Lebensbild nach Briefen und anderen Quellen, Görlitz, Starke, 1930.

${ }^{51}$ Franz Francke, 'Ueber den Antheil des Körpers an Erzeugung psychischer Krankheitszustände', Zeitschrift für die Anthropologie, 1824, 7: 257-338, on pp. 264, 268.
}

52 Ibid., pp. $330-1,289$.

53 Ibid., p. 259.

${ }^{54}$ C F Nasse, 'Von der psychischen Beziehung des Herzens', Zeitschrift für psychische Ärzte, 1818, 1: 49-116, on pp. 73-4.

55 Maximilian Jacobi, 'Beobachtungen über die Pathologie und Therapie der mit Irreseyn verbundenen Krankheiten', in idem, Sammlungen für die Heilkunde der Gemüthskrankheiten, Elberfeld, Schönian'sche Buchhandlung, 3 vols, 1830, vol. 3, p. 359; cf. also, ibid., vol. 1, pp. 43-5. The Sammlungen combined three of Jacobi's texts from 1822,1825 , and 1830 . His main work dated from 1830 , though, as Dörner notes, the cornerstones of Jacobi's theory were already developed in 1822 , op. cit., note 39 above, p. 277. 


\section{J C Prichard's Concept of Moral Insanity}

\section{Humoralism versus Phrenological Materialism}

That the viscera could lie at the roots of madness Prichard had already said in 1822. But then, he had seen the emotions and the understanding as mental faculties which were untouchable by organic operations. The Nasse school, too, directed their efforts against phrenology, but, unlike Prichard, they had no qualms about theorizing on the interrelationship between body and mind. Jacobi, in particular, criticized the traditional approach to madness which, in his opinion, had always wrongly focused on the understanding. For the nosology of madness, as he saw it, the emotional framework was more important than the understanding. ${ }^{56}$ "The melancholic", Jacobi said, "is not plunged into his disease by virtue of this or that sad idea, rather the idea arises because he suffers from some such disease". Prichard quoted the phrase approvingly when reporting a case where he himself had acted as the consulting physician. ${ }^{57}$ According to the Nasse school, at the onset of most cases of madness there existed a derangement of the emotions brought about by a disease in parts of the organism. This could - but need not necessarily-lead to a deranged understanding. ${ }^{58}$ While the latter disease was indeed seated in the brain, ${ }^{59}$ dislocated emotions signified a disease of the visceral organs, be it the heart, the liver, the stomach or a part of the intestines. ${ }^{60}$ Thus the way was paved for the pathology of moral insanity.

In pitting the diseases of the passions against those of the intellect, the Germans relied heavily on the time-honoured doctrine of humoralism. ${ }^{61}$ As a faculty whose functioning was clearly dependent on the brain, the understanding was open to anatomical investigations. Not so the passions: their expression was a matter of the body's physical constitution. Humoralist doctrines were used to theorize and classify them. In Jacobi's words, the task was to investigate "the temperaments as somatic basis of the affective powers and the passions". ${ }^{62}$ While, in 1822, Prichard was not interested in the temperaments, by the mid-thirties he explicitly applied humoralism to the nosology of madness. ${ }^{63}$ In his article on the 'Temperaments' in the Cyclopaedia of practical medicine he relied heavily on German sources, and on Jacobi's publications in particular. ${ }^{64}$ The

\footnotetext{
56 Jacobi, ibid., vol. 1, pp. 38, 52.

57 Ibid., p. 44. Quoted in Prichard, op. cit., note 2 above, pp. 29-30.

58 Ibid., p. 43 (“. . . und erst nachdem die Gemüthsstörung zur Wirklichkeit gekomen ist, und auch die Phantasie ... erkrankt ist, tritt

Verstandesstörung ein. Dieses Ursprunges sind alle

Hauptformen der Seelenstörungen, die man daher mit

Recht Gemüthskrankheiten nennt ....").

59 Ibid., p. 58.

60 Ibid., p. 34 (Jacobi talks about "krankhafte Wechsel in der Materie und Veränderungen in der Organisation").

${ }^{61}$ Even though Jacobi asserted that the second volume of the Sammlungen dealt mainly with the temperaments (ibid., vol. 2, p. vii), this side of his theory has hardly been given any consideration. Only one historian mentions humoralism in the context: Edward Hare, "The history of "nervous disorders" from 1600 to 1840 , and a comparison with modern views', Br. J. Psychiatry, 1991, 159: 37-45, on
}

pp. 41-2. For general accounts of humoralism in the epoch see Antoinette Emch-Dériaz, 'The non-naturals made easy', in Roy Porter (ed.), The popularization of medicine 1650-1850, London, Routledge, 1992; William A Lishman, Organic psychiatry, Oxford, Blackwell, 1990; Owsei Temkin, Galenism: rise and decline of a medical philosophy, Ithaca, Cornell University Press, 1973, p. 180 ff. In his programmatic article in the first volume of the Zeitschrift, Nasse too professed his adherence to humoralism. See Nasse, 'Ueber die Benennung und die vorläufige Eintheilung des psychischen Krankseyns', Zeitschrift für psychische Ärzte, 1818, 1: 1-48, on pp. 39-40.

62 Jacobi, op. cit., note 55 above, vol. 1, p. 70.

${ }^{63}$ Prichard stressed that "a certain peculiarity of natural temperament or habit of body is a necessary condition for the development of insanity" (op. cit., note 2 above, p. 157), he adopted a classification of madness derived from humoralism (ibid., pp. 168-9).

64 Prichard, 'Temperament', in op. cit., note 1 above, vol: 4 , pp. 159-74. 


\section{Hannah F Augstein}

nineteenth-century version of humoralism did without the notion that any given temperament was due to the superabundance of a particular bodily fluid. Instead, as Francke put it, temperament referred simply to "the specific individual constitution of physico-psychical life". ${ }^{65}$ This implied, in Jacobi's words, that "there are as many different temperaments as there are different individuals". ${ }^{66}$ Prichard expressed himself in a similar manner. After having declared that moral insanity referred to the "preternatural excitement of the temper and spirits", he specified that "in fact, the varieties of moral insanity are perhaps as numerous as the modifications of feeling or passion in the human mind". 67

In this interpretation, the temperaments were being proffered as indicators of man's psychological constitution. ${ }^{68}$ Jacobi contended that "the impact which the brain exerts on the psyche [was] far less well established" than that of the temperaments. ${ }^{69}$ Humoralism was used to found a bodily system of emotions which could not be explained by reference to processes within the brain. The latter was responsible for matters concerning man's intellect, while the particular humoral constitution of the body determined his moral conformation. Thus Jacobi mustered humoralism against modern phrenological materialism. ${ }^{70}$ The second volume of his Sammlungen was devoted to anthropological investigations executed along humoralist lines and dedicated to the rejection of phrenology. Prichard took up the torch: indeed, "the varieties of temperament and the peculiarities of organization belonging to individuals are so related to predisposition to mental disease", that he declared himself "anxious to give a brief and distinct statement" about them. He appended a long 'Supplementary note on peculiar configurations of the skull' to his treatise where he discussed the matter, in order to prove that the psychological systems of the phrenologists were wrong. ${ }^{71}$

\section{The Instincts}

The emphasis on the humoral doctrine linked up with a reconsideration of the role of instincts. During the eighteenth century, instincts had been regarded as the base animal counterpart of divine human rationality. At the beginning of the nineteenth century, however, their status was remodelled. For Prichard, the work of the physician Thomas Hancock (1783-1849) was of decisive importance. The two men had studied together at

${ }^{65}$ Francke, op. cit., note 51 above, p. 291.

66 Jacobi, op. cit., note 55 above, vol. 1, p. 67.

${ }^{67}$ Prichard, op. cit., note 2 above, p. 17. Roger Smith has rightly pointed out that this phrase lent itself to subsequent misinterpretations of moral insanity, he does not, however, link Prichard's opinion to the humoral tradition, (op. cit., note 6 above, p. 114).

${ }^{68}$ In general terms, this interpretation is supported by S W Jackson, 'Galen on mental disorder', J. Hist. Behav. Sci., 1969, 5: 365-84, on p. 382. Jackson notes that "certain" of Galen's "views and practices seem to have kinship with modern psychogenic theories and psychotherapies".

\footnotetext{
69 Jacobi, op. cit., note 55 above, vol. 1, p. 137.

${ }^{70}$ Ibid., pp. 64-6. For Jacobi, it was not just physiology which determined the psyche. The mechanism functioned vice versa at least as reliably. Prichard must have taken particular interest in Jacobi's claim that a change of religion led to a change of the physiology: "Mahometans and Christians can be recognized in their bodies. When a Mahometan turns into a Christian, bodily too he becomes a new man", ibid., vol. 2, p. 327.

${ }^{71}$ Prichard, op. cit., note 2 above, pp. 169-70, 461-80.
} 
Edinburgh, and had remained friends ever since. ${ }^{72}$ Hancock was a Quaker whose metaphysical earnestness none could doubt. In his Essay on instinct and its physical and moral relations, he rescued the instincts from their low status in brutish nature. Starting from Thomas Reid's and Dugald Stewart's philosophy, Hancock asserted that instincts were characteristic of man as well as animals. ${ }^{73}$ It was wrong to see them as the brute substitute for human rationality: ${ }^{74}$ they belonged to that part of the constitution of which the living creature, human as well as animal, was not consciously aware. ${ }^{75}$ But although they were innate, instincts were modifiable. Most notably, domestication led to an animal's loss of its natural instincts. ${ }^{76}$ Hancock did not see this as altogether desirable. Not only were domesticated animals predisposed to catch new forms of disease, but their natures could also be altered for the worse. The beaver in the native state was, according to Hancock, "politic, vigilant, social, labouring incessantly for the public good"; in captivity, however, all these positive characteristics disappeared. ${ }^{77}$ The analogy between animals and man was easily made. Hancock praised the "pure and natural state" of the human senses while he saw with critical eyes what civilization did to them: "as men, the more they degenerate, grow the vainer, they come at last to believe that without divine assistance by their own wisdom merely they may be happy". This statement flowed from Hancock's belief that morality was not a question of rationality: "Reason does not enable man to fulfil the ends of his creation", he wrote. ${ }^{78}$ The divinity had implanted a moral standard or "spiritual principle" in the human constitution; ${ }^{79}$ it formed part of man's instinctive fabric. ${ }^{80}$

Hancock fruitfully combined strong religious belief, the philosophy of the human mind, post-revolutionary Rousseauist criticism and the Romantic scepticism towards rationality. Prichard more than once mentioned the book at crucial points in his analyses, and it helped him to envision insanity as part of the human condition. ${ }^{81}$ Prichard's

\footnotetext{
72 John Addington Symonds, 'Some account of the life, writings, and character of the late James Cowles Prichard', in idem, Miscellanies, London, Macmillan, 1871, on p. 117. Born in Ireland, Hancock studied medicine at Dublin and Edinburgh, where he graduated in 1806. After he had spent twenty years as a physician to the City of London and Finsbury Dispensaries he moved to Liverpool and finally back to Ireland. During his London years he acquired a reputation as a writer on medical subjects (with articles on epidemics, fever, and contagious diseases) and as having a philosophic mind. With regard to the doctrine of revelation, Hancock tried to reconcile Locke's philosophy of the human mind with common-sense philosophy. His obituary stressed that "his works evince throughout them a tone of religious sentiment, well harmonizing with the author's deportment in life"; (see his obituary in London Medical Gazette, 1849, 8: 790; and Dictionary of national biography, vol. 24).

73 Thomas Hancock, Essay on instinct and its physical and moral relations, London, W Phillips, et al., 1824, pp. 52-101.

${ }^{74}$ In his translation of Buffon's Natural history, Smellie had made this point. Afterwards many conservative-minded naturalists refuted the idea. See,
}

e.g., H C Trenchard, 'On the distinction between instinct and reason', Bath and Bristol Magazine, 1834, 3: 147-55. See also Hancock, op. cit., note 73 above, pp. 11-13.

${ }^{75}$ See ibid., ch. 6, 'The ascending scale of instinctive or unconscious motions', p. $112 \mathrm{ff}$.

76 Ibid., p. 109.

77 Ibid., pp. 55, 59.

78 Ibid., pp. 192, 173.

${ }^{79}$ Ibid., p. 315 and ch. 9 'Of the divine spirit in the soul'.

${ }^{80}$ Ibid., p. 196 and Part II 'Of the moral relations of instinct', p. $197 \mathrm{ff}$.

$81 \mathrm{~J} C$ Prichard, $A$ review of the doctrine of a vital principle, as maintained by some writers on physiology with observations on the causes of physical \& animal life, London, John and Arthur Arch, 1829, p. 63 ("the relations which the faculties of brutes bear to those of man have been admirably illustrated by Dr. Hancock, in his Essay on Instinct"); idem, Researches into the physical history of man, 5 vols, London, Sherwood, Gilbert, and Piper, $1836-47$, vol. 1 , on. p. 174; idem, op. cit., note 2 above, p. 189; Prichard quoted a title with a slightly different wording from Hancock's original. Since, as far as I know, Hancock published on the subject only 


\section{Hannah F Augstein}

elaborate system of exciting and predisposing causes of madness fitted neatly with the modernized form of humoralism and Hancock's Essay on instinct. As for the exciting causes, Prichard distinguished between moral and physical causes. To the former he ascribed much greater impact: "a more decided preponderance will appear on the side of moral causes as the principal agents concerned in the development of mental disorders". 82 But irrespective of the nature of the "accidental excitements", madness could break out only if the exciting causes met with a bodily predisposition to madness:

A certain peculiarity of natural temperament or habit of body is a necessary condition for the development of insanity: without the previous existence of this condition the causes which give rise to the disease will either act upon the individual without any noxious effect, or they will call forth some other train of morbid phenomena. ${ }^{83}$

This medical distinction between predisposing and exciting causes-standard knowledge-had an important role within Prichard's theory, for he added that the predisposition to insanity was part of human nature. Referring to Hancock, Prichard declared: "it may be said in one sense that a preparation is made for this species of derangement [madness] in the constitution of the human mind". 84

Prichard came to this conclusion through extending Hancock's hypothesis on the loss of animal instincts under the conditions of domestication to human cultures of varying degrees of civilization. He held the widespread notion that with the increasing refinement of society madness was increasing also. Hancock helped him to account for that phenomenon in a manner which would not call in question the perfection of creation. A propensity to madness was nothing less than a necessary corollary of the human ability to survive. While in animals the sense of self-preservation operated unconsciously or instinctively, human nature was endowed with the faculty of foresight: "Hope and fear, anxiety respecting the future, are the principles in human nature by which the care of selfpreservation is insured". 85 Hope, fear, and anxiety were deeply ingrained in the human psyche, they were inherent to man's nature and hence beyond the control of rationality.

This theory had a desirable side-effect. Etienne de Condillac and his followers thought that animal instincts were reducible to habit and experience. So, to do the opposite and bolster the role of the instincts as part of the body's constitution as a whole amounted to a refutation of sensationalism and its derivative schools. Thanks to Hancock, Prichard was able to appreciate theories which emphasized the significance of madness as a phenomenon of the body's essential make-up. It was a crucial spur to Prichard's growing interest in the psychological nature of man as understood by German anthropologists and alienists.

\section{German Influence on Prichard}

Prichard was not the only mad-doctor to discover the significance of German theories on madness. Before him, Philippe Pinel, taking the same course, had also arrived at the notion of emotional disorders. ${ }^{86}$ But in Britain Prichard was the first to utilize the full

the above mentioned book, it is unlikely that Prichard had in mind a publication other than Hancock's Essay.

82 Prichard, op. cit., note 2 above, p. 174.
83 Ibid., p. 157.

84 Ibid., p. 189.

85 Ibid., pp. 350, 189.

86 Pinel, op. cit., note 42 above. 


\section{J C Prichard's Concept of Moral Insanity}

potential of the German approach. ${ }^{87}$ German theories of the human mind as well as of madness were native to German intellectual traditions. To some extent this was a question of language: the German word Gemüt has no exact equivalent in English. Prichard translated it as "sentiment", but Gemüt is more than that. It refers to the emotional disposition or the moral framework of man, and relates to the understanding, as heart relates to brain. Hence German semantics suggested a classification of madness which naturally included the notion of diseased emotions. It enabled Prichard to regard the passions as ontologically distinct from the other faculties of the mind. ${ }^{88}$

While Prichard referred the passions and the understanding to the realm of physical materiality, there was one faculty which was exempt. Following the German distinction between the mental faculties, Prichard conceived not only the complementary duality of sentiment and understanding, but also added a third principle, judgement, the English term for Vernunft. Unlike the powers of sentiment and understanding, this third component of German idealist philosophy remained the link between man's mind and God's spirit. In English, understanding, reasoning and judgement are not always clearly distinguished. Prichard, too, confused them. In German, by contrast, due not least to Immanuel Kant, the terms Vernunft and Verstand are endowed with different meanings. ${ }^{89}$ In 1835, Prichard surrendered to physical causes both the emotions and the understanding, i.e. "the intellectual" and "the ethical or moral department of the mind": both might be perverted by external impressions, whether of a moral or a physical nature. ${ }^{90}$ But Prichard believed that the faculty of judgement was in a certain way removed from the influence of external stimuli: "The individual can reason soundly on all subjects, only he can never be brought to doubt or to exercise his faculty of judging and reasoning on the subject of this false impression. ${ }^{" 91}$ As in 1822 , he argued that this faculty was only mediately connected to the external world. He referred to the recent publications of the French philosopher Pierre La Romiguière who, employing Kant's philosophy, had asserted the independence of the faculty of judgement from the operations of the senses..$^{92}$ The notion that the judgement could judge everything except itself was a characteristic element of German idealist philosophy. Starting with the Lancet in 1835 , commentators tended to believe that moral

\footnotetext{
87 Weiner mentions that Crichton too was an avid student of German texts. But much as Crichton emphasized the role of the passions for the rise of insanity, he did not perceive that the passions themselves might be diseased; see Dora Weiner, 'Mind and body in the clinic: Philippe Pinel, Alexander Crichton, Dominique Esquirol, and the birth of psychiatry', in George S Rousseau (ed.), The languages of psyche: mind and body in Enlightenment thought, Berkeley, University of California Press, 1990, esp. pp. 334-6. Cf. Alexander Crichton, An inquiry into the nature and origin of mental derangement, comprehending a concise system of the physiology and pathology of the human mind and a history of the passions and their effects, 2 vols, London, T Cadell Jr and W Davies, 1798, vol. 2, bk. 3, 'On the passions and their effects'.

${ }^{88}$ Traditional British nosology was based on the differentiation between the "active" and the "intellectual" powers of mind (cf. Roger Smith, op.
}

cit, note 6 above, p. 38). But as Prichard's 1822 Treatise illustrates, this division introduced no genuine differentiation in the analytical treatment of the two. Spurzheim was one of the first to assign two different seats-both of them, of course, situated in the brain - to the emotive and the intellectual faculties respectively; cf. Oehler-Klein, op. cit., note 28 above, p. 330.

${ }^{89}$ For a contemporary English account of Kant's terminology see the glossary in A F M Willich, Elements of the critical philosophy; containing a concise account of its origin and tendency; a view of all the works published by its founder, Professor Immanuel Kant . . , London, Longman, 1798.

${ }^{90}$ Prichard, op. cit., note 2 above, p. 10.

${ }^{91}$ Prichard, op. cit., note 2 above, p. 120.

92 In his time, La Romiguière was interpreted in very diverse ways. Prichard learnt about his theories through the Belgian alienist Joseph Guislain, cf. Prichard, op. cit., note 2 above, p. 118-19. 


\section{Hannah F Augstein}

insanity was developed merely within the framework of common-sense philosophy. ${ }^{93}$ This, however, is at best half the truth. It was only by virtue of the German idealist philosophy of mind which assigned judgement its special cognitive position, that Prichard could accept the notion of unbalanced mental faculties such as perverted emotions and deranged understanding, without consigning the soul to the realm of physical causation. ${ }^{94}$ And this in turn enabled him to associate the emotions with the bodily constitution, whence he derived a theory of psychical disorder which was designed to defy the phrenological system.

Hitherto, many historians have regarded the intellectual struggles over the relationship between the body and the mind in the 1820s and 1830s mainly as a binary opposition between two camps: the physicalists or somatists versus the spiritualists-as they are called in France-or the mentalists as they are referred to in England. ${ }^{95}$ Indeed, Maximilian Jacobi was in his time the spearhead of the somatists who attributed the aetiology of mental diseases exclusively to the body, and he was deeply embroiled in quarrels with the rival faction of the psychicists, represented by Heinroth. However, their skirmishes must not be translated into the handy dichotomy between "materialist" somatists and "pious" psychicists. As Verwey has rightly stressed, the quarrels between the two factions did not amount to the simple antagonism between body-centred and mind-centred explanations for insanity. It is true that they argued with each other over whether the aetiology of mental diseases should be placed in the body or in the soul. This difference was mirrored in their politics: the Somatists tended towards liberalism, while the followers of Heinroth harboured a more conservative outlook which led them to view mental disorder as a product of immorality. ${ }^{96}$ But they all spoke as one when it came to fighting "the one-sided, physically-oriented, 'mind-less' medicine of the Aufklärungs era". 97

In the desire to leave the realm of the immaterial soul untainted by physicalist theory, the Nasse school applied, as it were, the mind-body dualism to the relationship between parts of the body itself. While materialist physiology had chosen the brain as its stronghold, the somatists focused on the rest of the body as the realm which was

\footnotetext{
93 An anonymous reviewer of the Treatise on insanity wrote: "Let Dr. Prichard, however, confess that nearly all this new light on the subject of moral insanity has burst on M. Esquirol, on himself, and on the Scotch metaphysical school, since the appearance of Gall's immortal work on the anatomy and functions of the brain"; Lancet, 1834-35, ii: 703-5, on p. 705 . See also the references in note 7 above.

94 A good treatment of Kant's role in the German alienist tradition is in Dörner, op. cit., note 39 above, pp. 185-328. For the impact of Kant's philosophy on the natural sciences see Frederick Gregory, 'Kant's influence on natural scientists in the German Romantic period', in Robert Visser, et al. (eds), New trends in the history of science: proceedings of a conference held at the University of Utrecht, Amsterdam, Rodopi, 1989 pp. 53-66; Guenter Risse, 'Kant, Schelling and the early search for a philosophical "science" of medicine in Germany', $J$. Hist. Med., 1972, 27: 145-78; idem, "Philosophical"
}

medicine in nineteenth-century Germany: an episode in the relation between philosophy and medicine', $J$. Med. Philos., 1976, 1: 72-91.

95 See, e.g., Dörner, op. cit., note 39 above, p. 266; Goldstein, op. cit., note 11 above, pp. 247, 249, 257; Scull, The most solitary of afflictions, op. cit., note 9 above, pp. 216-31; Smith, op. cit., note 6 above, p. $40 \mathrm{ff}$.

96 Dörner has emphasized the liberal politics of the "somatic school" among German alienists some of whom indeed came to sit in the parliament of the Paulskirche in 1848 . He does not, however, give their religious ethics its due; Dörner, op. cit., note 39 above, pp. 273-9.

97 Verwey, op. cit., note 43 above, p. 8. Jacyna too has pointed out that the juxtaposition of "moral" theories of insanity and a physicalist aetiology is "over-simple", L S Jacyna, 'Somatic theories of mind and the interests of medicine in Britain, 1850-1879', Med. Hist., 1982, 26: 233-58, p. 233. 


\section{J C Prichard's Concept of Moral Insanity}

expressive of, and governed by, forces which were neither rational nor even connected to the organ of rationality. But they were not materialists. In the end the very notion of an organism whose parts, through the mechanism of sympathy, were all linked to each other as well as to the soul, contradicts this interpretation. Jacobi's insistence on physical sources of madness did not aim to reduce the operations of the mind to physical causes. Rather he was defying the attempts of Pinel and Heinroth to explain all mental phenomena through occurrences of which the individual was conscious or could at least give an account. He rejected Heinroth's emphasis that madness was the outcome of sin. And he poked fun at Pinel's assumption that a madman himself might be able to explain what plunged his mind into disorder. ${ }^{98}$ Pinel too regarded inflammation of the viscera as a source of mental disorder. ${ }^{99}$ But in Jacobi's opinion, Pinel had made a bad choice when he rejected the diagnostic system of humoralism in favour of the practice of asking his patients whether they had experienced "distress or misfortunes". ${ }^{100}$ This was a naive and ludicrous approach to diagnosis: "Who has not experienced distress or misfortunes?", Jacobi asked rhetorically. ${ }^{101}$ If madness struck, it was the result of the disposition and constitution of the individual, not of problems which were part of human life.

Despite opposing this psychological approach to diagnosis, Jacobi was not against psychological explanations in general. But for him, that part of man's mental framework which was open to medical treatment was mediated through the bodily constitution. After all it was here where sentiments made themselves felt: anxiety infested the stomach, sadness infected the heart; here "madness lights up the candles which create the illusions that lead the understanding into the wrong". ${ }^{102}$ In the theories of the somatists, physiological tenets joined with the repertoire of Romantic criticism. To regard madness primarily as a disease of the viscera was a corollary of the fact that Romanticism considered the understanding as the poorer, merely instrumental part of the human character. Accordingly, the brain as the instrument of the understanding was of lower transcendental value than those organs which were in bilateral intercourse with the emotions. Ás Jacobi put it, "the holiest powers of man which constitute his actual value, his humanity, reside in his sentiment [Gemüth]". ${ }^{103}$ In short, for the German somatists, the visceral organization of the body had more to do with the transcendental nature of man than had the brain, and this was the idea that lay behind Jacobi's quip that "there are certain morbid changes in the organisation" which ultimately lead to an impairment "of moral freedom". 104

\footnotetext{
98 Jacobi, op. cit., note 55 above, vol. 1, pp. 78-9, vol. 2, p. 403. Cf. J C A Heinroth, Lehrbuch der Störungen des Seelenlebens oder der Seelenstörungen und ihrer Behandlung. Vom rationalen Standpunkt aus entworfen, 2 Theile, Leipzig, F C W Vogel, 1818.

${ }_{99}$ Pinel, op. cit., note 42 above, p. 17.

100 For Pinel's renunciation of humoralist diagnostics see Dora Weiner, "LLe geste de Pinel": the history of a psychiatric myth', in Mark S Micale, Roy Porter (eds), Discovering the history of psychiatry, Oxford University Press, 1994, on p. 235.

101 Jacobi, op. cit., note 55 above, vol. 3, p. 93.

102 “... . im Herzen zündet der Wahnsinn die Lichter an, durch welche die Trugbilder entstehen, die den Verstand irre leiten; im Herzen keimt die Narrheit auf
}

\begin{abstract}
...; im Herzen schlägt die Melancholie zuerst ihre dem Leben verderblichen Wurzeln" (ibid., vol. 1, p. 43). 103 Ibid.

104 Ibid., vol. 1, p. 34. Jacobi believed “daß Wechsel und Veränderungen der Materie und Organisation in einem ausserordentlichen Grade statt finden können, ohne daß die Aeußerung der Freiheit nur im mindesten dadurch beschränkt wird. Auf der andern Seite lehrt indessen die Erfahrung ebenfalls, $\mathrm{da}$ es gewisse krankhafte Wechsel in der Materie und Veränderungen in der Organisation giebt, während deren Vorhandenseyn die moralische Freiheit oder das Wirken der Vernunft, durch ein bedingtes Leiden der Gemüths- und Verstandeskräfte gebunden erscheint." (My emphases.)
\end{abstract}




\section{Hannah F Augstein}

So far, the doctrines which Prichard shared with the Nasse school can be summarized thus: 105

(1) They saw insanity as an organic disorder with, quite often, its primary seat in the viscera and not in the brain.

(2) They referred to a modernized form of humoralism to establish a matrix which made emotions nosologically amenable. This went together with a new interest in the systematic exploration of human psychology. The emergent discipline of psychology was intertwined with anthropology and medicine. Man's psychological framework paralleled, on a higher level, animal instincts. The individual human psyche was the result of the interaction between the individual (humoral) constitution and the external environment. Hence the faculties of rationality and emotions could no longer be regarded as purely spiritual.

(3) Their theories of madness accounted for the perversion of the emotions and the understanding. In so far as they referred mental faculties to material nature, they advanced theories akin to materialism. But unlike materialists, they assigned the faculty of judgement a special position: it remained aloof, being principally separated from the realm of nature.

(4) They consciously formulated theories of madness which reflected their dismay about contemporary materialistic tendencies. In particular they strove to defy the phrenological threat through the combined efforts of their anthropological and physiological endeavours. In general, their scholarship was imbued by the metaphysical project to validate the transcendental nature of man within the language of science.

\section{Prichard's Conversion to Jacobi's Theory}

Although Prichard followed Jacobi's theory in many particulars, in the 1830s he was not ready to admit a relationship between the concept of moral insanity and Jacobi's doctrines of the pathology of madness. This was due to the materialistic connotations of somaticism. Prichard disowned the brain as the seat of the emotive faculties, so that it could not be taken as the seat of the soul. ${ }^{106}$ However, he was not prepared either to let in materialism through the back door by admitting that all mental states were ultimately the result of bodily conformations. This was what, in the eyes of many of his contemporaries, Jacobi's somaticism amounted to. As we have seen, Jacobi was deeply pious. None the less, many objections to his stance in the physicalist-mentalist debate were raised by religious critics. Also, his claim that madness was a non-cerebral disorder agreed in some particulars with the views of Broussais who was condemned for his materialism. In 1835 Prichard was sceptical of Broussais's attempt to refer insanity to "irritations . . . in the digestive organs", that was "a position which, before it can be admitted, requires proof; and no such proof has been afforded". For the same reason, Prichard denounced Jacobi's

\footnotetext{
105 In some respects the following catalogue is true for Esquirol as well. The basic rift between Prichard and the Nasse school on the one hand and Esquirol on the other lies in Esquirol's "straightforwardly 'physiological'" approach, his penchant towards sensationalism and positivisim, and his rejection of psychology as a discipline, see Goldstein, op. cit., note 11 above, pp. 247, 249, 257.
} 


\section{J C Prichard's Concept of Moral Insanity}

nosology as "extreme". At the same time, however, he was intrigued by the idea that explained mental diseases as a result of gastro-enteric disorders. ${ }^{107}$

Another theory which strove to explain madness as a disease of the viscera was Pinel's "manie sans délire". ${ }^{108}$ Like Prichard's moral insanity, it conceived of a form of madness which did not involve a derangement of the understanding. But unlike Prichard, who conceived extreme eccentricity as a typical syndrome of moral insanity, Pinel had characterized "manie sans délire" as a frenzy of the passions, involving great rage and violence. Prichard could not reconcile himself to the idea that simple disorders in the bowels could induce "that intense excitement of malevolent propensity which leads to murder and suicide". 109

In his view, all extreme positions based on ambiguous pathological investigations were suspect: it was wrong to define madness as a function of cerebral disorder, and équally mistaken to attribute it merely to the viscera. As a safeguard against that position Prichard retained the brain as the organ which mediated between the external world and human conscience. He favoured the notion "that particular conditions of the brain are intermediately and instrumentally co-operative, and interposing themselves between the disorder of the organ primarily affected, and the state of mind or temper which is traced as its manifestation or accompaniment". ${ }^{110}$ Thus Prichard repeated his theory from 1822. ${ }^{111} \mathrm{He}$ introduced the Belgian alienist Joseph Guislain as an authority who had set out the same idea. Guislain was also the author to whom Prichard referred in order to differentiate between the faculty of judgement and other mental faculties. ${ }^{112}$ The correlation shows Prichard's tendency to let philosophy take precedence over anatomical assumptions. As for the anatomical evidence itself, Prichard relied on the theories of Achille-Louis Foville, whom he understood to have combined the idea of insanity as cerebral inflammation with the notion that in some cases the disease was located in the viscera. ${ }^{113}$ Prichard tried to steer a middle way between all possible positions. None the less, even to him the results were not altogether satisfactory: moral insanity in particular posed a problem. Why should a type of disorder which did not involve the understanding but only the emotions leave its imprint on the anatomical make-up of the brain? Indeed, Prichard concluded that "the instances of mental disorder which leave the greatest doubt with respect to the presence of disease in the brain are those of moral

107 Ibid., pp. 113-14, 242.

108 Pinel, op. cit., note 42 above, Sect. IV.

109 Prichard, op. cit., note 2 above, pp. 246, 114.

110 Ibid., p. 246.

111 He himself referred to his 1822 Treatise on this point, Prichard, op. cit., note 2 above, p. 148. Cuvier had advanced the same opinion before the Académie des Sciences when he read out his judgement on the system of Gall and Spurzheim; see Clarke and Jacyna, op. cit., note 28 above, p. 276.

112 Prichard, op. cit., note 2 above, p.117.

113 Prichard praised the "remarkable accuracy" of Foville's pathological researches. See Prichard, "An address delivered at the third anniversary meeting of the Provincial Medical and Surgical Association, July 23d, 1835', in Trans. Prov. med. surg. Ass., 1836, 4: 1-54, pp. 18-19. Indeed, Prichard thought that in Foville he had found a fellow-combatant against phrenology, believing that Foville was "at issue with the followers of Gall", cf. idem, op. cit., note 2 above, p. 480 . This was totally erroneous. In fact, Foville-no less than the bulk of the Esquirol circle-was intrigued by phrenology; cf. Goldstein, op. cit., note 11 above, p. 256 . With regard to Foville's opinions on the viscera, it seems that Prichard exaggerated the former's statements. A reviewer of the Treatise on insanity pointed out that Prichard had not quite grasped Foville's theory, see [Anon.], 'Greco, Farr, Crowther, \&c. on insanity', in Br. for. med. Rev., 1839, 7: 1-55, on p. 31. Indeed, Foville tried to prove that the cerebellum was the seat of sensation; see Clarke and Jacyna, note 28 above, pp. 297-8. 
insanity". Had Prichard designated the brain as the locus of the passions and the sentiments, he would not have had this problem. But his theoretical opposition to phrenology, which induced him to see the sentiments as part and parcel of the overall bodily constitution, necessarily led him into this aporia. In other words, he had devised moral insanity in order to fight the phrenologists, but once the forces of the body were unleashed, they appeared to threaten his dualist world view.

It was only between the late 1830 s and early 1840 s, that he finally made up his mind and yielded to the theories of the Nasse school, accepting moral insanity as a disease of the viscera. In 1844 Prichard published a brief article reporting a typical case of moral insanity and revising his former position. ${ }^{114}$ Now he praised Jacobi wholeheartedly: his "various works on subjects connected with insanity, equally remarkable for the practical sense as for the deep philosophical investigation which they display, entitle their author to the highest rank among the living writers of this class."115 Neither Prichard, nor Jacobi had changed his theoretical approach to insanity. Nor had Prichard read texts by Jacobi which presented the German alienist in a new light. The truth is that Prichard had come to see Jacobi with other eyes. We have seen that he founded his views on the participation of the brain in mental disorder on a publication by Guislain. Jacobi had, in 1830, argued against Guislain's theory, Prichard had taken notice of it, without, however, assigning any importance to Jacobi's criticism. ${ }^{116}$ By 1844 , in contrast, this was exactly the passage which Prichard summarized in order to point out the similarity between his views and those of Jacobi. He wrote:

Jacobi has not expressed his opinion precisely in this manner; but it would appear . . . that he looks upon effects produced upon the sensorium and the mind, through the medium of the stomach, or any of the viscera of physical life, as not less immediately brought about by the action of the material organism on the intellectual or sensitive power, than the impressions produced in the mind by a blow on the head, or by any powerful agency exerted immediately on the brain.

The sequence of events as Jacobi saw it was, Prichard continued, intimately related to his own theory of moral insanity. More expressly than before, he presented moral insanity as a disease whose very existence proved the wrongfulness of phrenology:

The phenomena of moral insanity, or of a disordered state of the affections and moral feelings, without any corresponding lesion of the understanding, or of the reasoning faculties, furnishes, or appears at least, prima facie, to furnish a firm ground whereon to maintain the negative position in regard to the participation, or, at least, the primary influence of the brain, in the development of an extensive series of psychological phenomena. ${ }^{117}$

If we ask why Prichard finally recognized the kinship between his ideas and those of the Germans, an explanation may be found in his frustration with the French medical scene. Alienists such as Pinel and Esquirol had been interested in the relation between men's passions and mental derangements. But this phase lasted for only two decades. After Esquirol's death in 1840, his pupils who, much more than Esquirol, employed

114 Prichard, op. cit., note 41 above.

${ }^{117}$ Prichard, op. cit., note 41 above, p. 323.

115 Ibid., p. 323.

116 Jacobi, op. cit., note 55 above, vol. 3, p. 89;

Prichard, op. cit. note 2 above, pp. 242-3. 


\section{J C Prichard's Concept of Moral Insanity}

physicalist theories which were not tempered by religiosity, took over the field of debate. By the 1830s, French theorizing upon madness was dominated by the anatomical approach and the attempt to depict correlations between cerebral lesions and mental disorder. ${ }^{118}$ Even Foville, whom Prichard had relied on in his 1835 Treatise, proved an enthusiastic phrenologist. ${ }^{119}$ Prichard did not conceal his exasperation with contemporary trends in anatomy. In 1844, he regretted that "in England and France, the principal, if not the almost undivided attention of anatomists has been directed to the discovery of morbid changes in the brain". The Germans, even though they were generally neither "more practical" nor "sound", had at least taken "a different course":

the school of Nasse, in particular, directed the attention of pathologists to connections which are often to be traced between the different manifestations of insanity and various morbid phenomena discovered after death in the organs subservient to physical life [i.e. the viscera]. ${ }^{120}$

After Esquirol's death, there was no French alienist left who stood in Prichard's favour. In other respects, too, the links between his theories and those of the French had been severed. It had been Esquirol himself who had rejected Prichard's definition of moral insanity. In his last publication, he insisted that in Prichard's "folie morale . . . intelligence is more or less disturbed". ${ }^{21}$ Also, Esquirol had insisted that Prichard's moral insanity had nothing to do with Pinel's "manie sans délire", and that an "outbreak of furious madness without delusion' . . . is very distinct from that form of mental derangement which I have described under the term 'Moral Insanity"'.122 Thanks to Esquirol's correction, Prichard came to distinguish between moral insanity and "instinctive madness". "It was observed.by M. Esquirol", he wrote with approval, "that this affection is totally distinct from that which I have described first in the Cyclopaedia of Practical Medicine". Instinctive madness comprised disorders involving violent fits of anger. ${ }^{123}$ Moral insanity, by contrast, was in general far less violent.

Prichard reconsidered his stance towards Jacobi after he lost sympathy for the French scene. I should like to suggest that the persistent menace of phrenology helped to drive Prichard into the arms of the Nasse school. He retained his assumption that the brain acted as a mediator between impressions of the mind and body, but now he conceded that

the most important thing, in a practical point of view, is to establish the fact that the principal and fundamental cause of insanity is, in many instances, to be sought, not in the brain, but in some other region of the body.

\footnotetext{
118 Weiner, op. cit., note 87 above, p. 388.

119 In 1840, Prichard's former praise of Foville had given way to a detached and even sceptical evaluation; cf. Prichard, op. cit., note 5 above, p. 127.

${ }^{120}$ Prichard, op. cit., note 41 above, pp. $323-4$.

121 Esquirol, 'Monomanie', op. cit., note 14 above, p. 5 .

122 Prichard, op. cit., note 2 above, p. 93; Prichard referred to Esquirol, op. cit., note 121 above, p. 63.

123 In 1842 Prichard treated instinctive madness and moral insanity separately in chs 5 and 9 of $O n$ the different forms of insanity, in relation to
}

\begin{abstract}
jurisprudence. Designed for the use of persons concerned in legal questions regarding unsoundness of mind, London, Baillière, 1842. So far, no historian who has dealt with Prichard's moral insanity has been aware of this distinction. Joel Peter Eigen is the most recent example, see Eigen, op. cit., note 6 above, pp. 77-9. This is important because Eigen interprets Prichard's moral insanity as related to the notion of disorders of the will. Had he heeded Prichard's emphasis that instinctive mania and moral insanity were two different nosological categories, he might have come to another conclusion.
\end{abstract}




\section{Hannah F Augstein}

Jacobi was credited with assenting to Prichard's theory of moral insanity, i.e., "that a mental disorder exists, fully to be recognised by particular trains of symptoms, in which the moral, not the intellectual, part of the human mind is essentially disturbed". 124 Prichard's little article from 1844 concluded the issues which have been discussed so far, namely his defiance of the phrenologists through the theory of moral insanity, and the notion that moral insanity was tied to a disorder in the viscera and thus to the entire constitution of the body.

\section{Moral Insanity: a Product of Self-Centredness}

How deeply the theory of moral insanity was informed by implicit belief systems which stood in an indirect and complicated relationship with medicine itself may become evident in the following example. Prichard presented the pathological findings in question as if he had only been waiting for anatomical evidence to prove that moral insanity arose from a disease of the viscera. He cited the case of "a lady highly accomplished, and of great mental endowments, pious, affectionate, and sincere" who suddenly became "low-spirited and hypochondriacal". At the same time she refused to eat. When her friends and family urged her, she complained about pains in the abdomen. "Her whole temper and character became changed. Formerly devoted to her duties, and to works of benevolence to others, she now thought only of herself, and her complaints". Finally, she was sent into an asylum where she "was induced, though not without great difficulty, and a constant threat of compulsion if she resisted, to take a moderate quantity of the most nutritious and digestible food". Subsequently she died. The dissection showed that her intestinal canal was beset with ulcers and tubercles. Now, instead of concluding, that this woman was not mad, but did indeed suffer terrible pain and therefore had reason to reject food, Prichard took the morbid evidence in the abdomen as testifying to the truth of his theory on moral insanity:

... the perpetual complaints made by the patient of pain and suffering in the abdomen had an organic cause, and were not unreal, as it had been sometimes suspected. As these complaints had been uniform, and had continued from the commencement of the disease, it may be inferred as highly probable that the organic disease in the intestinal canal had been coeval with the mental disorder, and the foundation of the whole train of morbid symptoms. The history of this case furnishes, on this view, an example of insanity mainly dependant on a diseased state of organs very remote from the brain. ${ }^{125}$

It is significant that Prichard described the patient as being obsessed with herself-"she now thought only of herself'. To identify self-centredness as a feature of insanity was common also among the members of the Nasse school. Thus Jacobi wrote that the "forces of selfishness" strive in man "against revelation", only by overcoming the "forces of nature" could man's soul liberate itself. But time and again, nature proved stronger. Jacobi concluded: "Nothing can stop man in this temptation, which threatens shattering and

124 Prichard, op. cit., note 41 above, p. 323.

125 Ibid., p. 324. Prichard added that "Serous effusion, indeed, existed within the skull; and this is known to be a very frequent phenomenon in cases of insanity", but he suggested that this might be "regarded rather as an effect than a cause" of madness. 


\section{J C Prichard's Concept of Moral Insanity}

extinction, but the firm belief in the Truth . . . of revelation". ${ }^{126}$ Unlike Esquirol's pupils in France, the somaticist branch of German Romantic physiology explicitly and persistently referred to metaphysical convictions; in their understanding, insanity was concomitant, as it were, with a break-up of the ties which linked an individual to his transcendental nature. ${ }^{127}$ In that sense, Prichard and Jacobi made common cause. Both of them partook seriously in the anxieties of their age, the uprooting of traditional hierarchies, subsequent social upheavals, a burgeoning acquisitiveness hitherto unknown, scientific materialism-it was all indicative of far-reaching moral depravity. In a speech in 1835, Prichard sighed about "these days, when intellect is deified and worshipped as the sole divinity". ${ }^{128}$ The country which seemed to furnish ample reason for misgivings was France. In the wake of the revolution, religious observance had reached an all-time low. Selfish passions were no longer held in check. Jacobi implicitly conflated socially egoistic behaviour with the exaggerated self-centredness of the insane. In the end, both were attributable to loss of religion. Prichard saw things similarly. He translated a passage from Jacobi on the moral debasement of the French: "the generality of men have their understanding impaired through the influence of lower passions, and of vices" which Jacobi considered as "so much the more prevalent" as the Christian moral standard was on the decline. ${ }^{129}$

For Britain, the writing was on the wall. In 1831, Prichard's home town Bristol was shaken by a riot of labourers and paupers. The major public buildings were burned down, troops were called in. In the end, not only were the chief rioters put on trial but also a military captain, the mayor and aldermen were arraigned for their "apathetic" conduct during the upheaval. ${ }^{130}$ In short, it seemed that nobody, neither the poor nor their betters, had lived up to their civic duties. Not only France, but Britain too gave reason for concern. $^{131}$

Esquirol, in his time the greatest and most influential authority on alienation in France, was politically conservative enough to provide Prichard with rich quotes on the detrimental effects of moral decline. But unlike Jacobi, Nasse and Prichard, Esquirol engaged with French positivism, and his theories did not revolve around notions of redemption and life after death. Hence Esquirol's misgivings as to the contemporary state of morality were tied rather more to the course of civilization than to the individual's readiness to transcend his own self. ${ }^{132}$ By the time Napoleon had been despatched to St. Helena, it was permissible for conservatives to cite Rousseau. For Esquirol, backed by

\footnotetext{
126 Jacobi, op. cit., note 55 above, vol. 2, p. 314 (“die selbstsüchtigen Triebe ... streben gegen die Offenbarung").

127 For the political and social implications of French medicine see Erwin H Ackerknecht, Medicine at the Paris Hospital, 1794-1848, Baltimore, Johns Hopkins University Press, 1967; Charles Coulston Gillispie, Science and polity in France at the end of the old regime, Princeton University Press, 1980; Martin L Gross, 'The lessened focus of feeling: a transformation in French physiology in the early nineteenth century', J. Hist. Biol., 1979, 12: 231-71.

128 Prichard, 'Address', op. cit., note 113 above, p. 39.

129 Jacobi, op. cit. note 55 above, vol. 1, p. 24, quoted in Prichard, op. cit., note 2 above, p. 196.
}

130 John Latimer, Annals of Bristol in the nineteenth century, Bath, Kingsmead Reprints, 1970, p. 178. For the historical context see Michael Neve, 'Natural philosophy, medicine and the culture of science in provincial England: the case of Bristol, 1780-1850, and Bath, 1750-1820', PhD thesis, University College London, 1984, ch. 4.

131 Martin Wiener has depicted the great Victorian anxiety that the demise of traditional hierarchies would inevitably lead to the loss of public order: Martin Wiener, Reconstructing the criminal: culture, law, and policy in England, 1830-1914, Cambridge University Press, 1981.

132 See note 105 above. 
Rousseau, it was evident that civilized man had so far departed from propriety and decency that madness must be on the rise. Prichard chose Esquirol's texts to express his own misgivings. ${ }^{133}$ "During the last thirty years," Prichard said through the words of Esquirol, "the changes which have taken place in our manners in France, have been productive of more cases of insanity than our political torments". With the demise of religious observance in France, Esquirol stated, "demonomania and superstitious madness have disappeared". But instead of ushering in an epoch which was mentally saner, this change caused the reverse to happen. The pivotal role of religion for the upkeep of social order was a commonplace in the early nineteenth century. Esquirol had established what happened in a country with weak religious foundations: "The influence of religion over the conduct of the people being weakened, in order to keep men in obedience governments have had recourse to police". This had a dire consequence; "it is the police which haunts weak imaginations. Asylums are filled with monomaniacs, who, fearing this authority, have gone mad upon the subject, and believe that they are constantly pursued."134

Esquirol deplored the substitution of selfishness for ethics:

A cold egotism has dried up all the sources of sentiment: there no longer exist domestic affections, respect, attachment, authority, or reciprocal dependencies; every one lives for himself; none are anxious to form those wise and salutary provisions which ought to connect the present age with those which are destined to follow it. ${ }^{135}$

The Burkean overtones in this passage are evident. But Burke's target, the revolution, was history. Esquirol was talking about another kind of social lesion, he called it "perfect selfishness", ${ }^{136}$ Jacobi called it Selbstsucht ${ }^{137}$-it was the disease of the age of capitalism. Many contemporaries perceived that they were living through a phase of change. The way in which they theorized this is indicative of their political standpoints as well as of their ontology.

Some writers attributed the apparent change of manners to a reorganization of society as a whole, or to a changed mode of production. Others would not follow the turn to sociological analysis in the course of which they saw morality being relativized and ruled out as an explanatory category. The notion of alienation was widespread. But some philosophers-most famously, of course, Karl Marx-came to see this as a socioeconomic phenomenon, whereas philosophizing physiologists such as Prichard, Jacobi, and Esquirol regarded it as a phenomenon which was staged within human consciousness. It expressed itself in terms of a separation between men's social identity and their metaphysically grounded morality.

The whole movement delineated so far, as well as Prichard's reliance on German theoreticians, characterizes not just his medicine, but also his anthropology. Prichard accounted for the different varieties of mankind by linking humoralism and environmentalism. Thus he could reject the notion of distinct human races, while at the

\footnotetext{
133 Prichard often, and especially when religious issues were touched upon, expressed as his own views remarks which other authors had made.

134 The passage was quoted in Prichard, op. cit., note 5 above, p. 115. The original is in Esquirol, 'De la lypémanie ou mélancholie', 401, in idem, op. cit., note 14 above, vol. 1 , pp. $398-481$.
}

\footnotetext{
135 The quote is from Prichard, op. cit., note 2 above, p.192. The original is in Esquirol, op. cit., note 14 above. vol. 1, p. 49.

${ }^{136}$ It was one of the ten salient characteristics of moral insanity; Prichard, op. cit., note 5 above, p. 113.

${ }^{137}$ Jacobi, op. cit., note 55 above, vol. 2, p. 314.
} 


\section{J C Prichard's Concept of Moral Insanity}

same time eschewing the pitfalls of external, i.e., "materialistic", determinism. ${ }^{138}$ In both anthropology and medicine, Prichard was concerned to fend off the growing importance attached to the brain and consequently the construction of hierarchies along the lines of increasing cerebral complexity. The latter amounted in his eyes to an erosion of individual moral responsibility. ${ }^{139}$

\section{Gloom as Part of the Human Condition}

Prichard's deep piety was tied to the framework of natural theology. In all his writings Prichard was involved in a scientific theodicy, questioning why it had pleased God to inflict man with madness. We have seen how Prichard took his views on this matter from Hancock's Essay on instinct, and how he explained insanity as part of the human constitution and as a necessary corollary to the human ability to entertain fear for the future. It was, however, not just the "anticipation of wants" which was implanted in the human soul, but also the expectation of "a state of existence after death". ${ }^{140}$ Human beings were endowed with foresight in order to survive during their earthly existence. Equally, the awareness of the Fall and of a future day of judgement was given to them so that they could govern their behaviour in such a manner as to deserve redemption on the day of atonement. Indeed, Prichard conceived of an inherent and eternal fear which was constitutionally implanted in men's mental fabric: "there is one feature common to them all," he wrote, "their prevailing character is gloomy . . . A persuasion of moral demerit or a consciousness of guilt has been deeply impressed upon the minds of men in all ages". ${ }^{141}$

It was certainly no accident that the word "gloom" appeared also in the context of insanity. In his contribution to Alexander Tweedie's Library of medicine, Prichard mentioned melancholy as characteristic of patients suffering from moral insanity: "persons in this state have no relish for the enjoyments of life; they express no feelings of consolation or happiness in the prospect of a future existence; they view everything through a medium of gloom". ${ }^{142}$ If gloom, then, tormented the sound as well as the unsound, what was the difference between the two states of mind other than a question of degree? When Prichard said that a disposition to madness was part of the human constitution, this must be understood as his way of saying that mankind paid with madness for the Fall. Without anxiety, fear, and gloom, men would not behave as they should in order to ensure their survival and redemption after death. ${ }^{143}$ But these very qualities were, so to speak, too much for the human constitution. Hence, in each individual case, the exciting causes which led to the outbreak of madness were merely the last straw. Mental sanity did not prevent the sound-minded from sharing in the gloom of damnation with

\footnotetext{
${ }^{138}$ See Prichard, op. cit., note 81 above.

${ }^{139}$ For a full assessment of Prichard's anthropology see my $\mathrm{PhD}$ thesis op. cit., note 45 above. Other accounts of Prichard's anthropology are in Bynum, op. cit., note 29 above, pp. 70-118; Stocking, op. cit., note 16 above, pp. ix-cxvii; idem, Victorian anthropology, New York, Free Press, 1987.

${ }_{140}$ Prichard, op. cit., note 2 above, p. 189, see also idem, op. cit., note 81 above, vol. 1, pp. 175-6.
}

\author{
141 Idem, op. cit., note 2 above, p. 190. \\ 142 Idem, op. cit., note 5 above, p. 113 (my \\ emphasis). \\ ${ }^{143}$ This interpretation is in line with Hilton's \\ account of the theological notion of guilt and \\ atonement during the first half of the nineteenth \\ century. Boyd Hilton, The age of atonement, the \\ influence of evangelicalism on social and economic \\ thought, 1795-1865, Oxford, Clarendon Press, 1988.
}




\section{Hannah F Augstein}

which the diseased were inflicted. The difference was only that the sane managed to pull themselves together and fulfil their daily duties, while the morally insane "remain . . . moping and silent in their beds." 144

This interpretation of Prichard's thoughts on mankind and madness is in line with the fact that he was very reluctant to accept the category of religious madness. He shared Heinroth's belief that piety was the best preventive against insanity. For Prichard, true Protestant belief simply could not plunge people into lunacy; in his opinion, it was never the prevalence but rather the loss of religion which made people prone to insanity. He defended this stance against the statistics which seemed to illustrate the contrary. ${ }^{145}$ And although he firmly rejected Heinroth's notion that madness was a disease of the immaterial mind, he sympathized with the idea that "moral depravity was the essential cause of madness". Heinroth's view had, for Prichard, "some foundation in truth ... Vices, inordinate passions, and the want of mental discipline" indeed tended "to increase the prevalence of insanity". 146

\section{The Social Significance of Moral Insanity}

An attempt has been made to show that moral insanity must be understood as a corollary of Prichard's conservatism in a struggle which was taking place on many levels: reform versus counter-revolution; materialist physiology versus organismic holism of body and soul; purely sociological versus "moral" or psychological explanations; secularization versus metaphysics. In this light I suggest that it does not make sense to interpret moral insanity as the concomitant of Prichard's endeavour to bolster the status of his profession. He did not aim at medically curbing the lower classes by putting forward moral insanity; nor did he devise the concept in order to facilitate a medical distinction between the good and the bad, the sane and the mad. Of course, there are non-medical origins of moral insanity, but these are to be found primarily in Prichard's moral convictions.

Stocking has repeated the suggestion, raised by Carlson and Dain, that Prichard's choice of the term moral insanity simply referred to "a weakness or disease of the moral sense". ${ }^{147}$ Against this allegation other historians stressed that Prichard's use of the term "moral" had no ethical allusions. ${ }^{148}$ In fact, however, both propositions have a point. For Prichard, moral insanity was a moral perversion in both senses, leading to a dislocation of the moral sentiment as well as of morality. Prichard knew that ethics had nothing do to with medicine, and yet he could not help finding some truth in Heinroth's theory that insanity rose out of sin. It linked up with his belief that the causes of moral insanity were,

\footnotetext{
144 Prichard, op. cit., note 5 above, p. 113.

145 Idem, op. cit., note 2 above, pp. 187-202.

146 Ibid., pp. 235, 238. As for an assessment of his theories see Luc S Cauwenbergh, 'J. Chr. Heinroth (1773-1843): psychiatrist of the German Romantic era', Hist. Psychiatry, 1991, 2: 365-84; George Mora, 'Introduction', in J C A Heinroth, Textbook of disturbances of mental life, or disturbances of the soul and their treatment, trans. J Schmorak,

Baltimore, Johns Hopkins University Press, 2 vols, 1975; Verwey, op. cit., note 43 above, pp. 9-22.
}

\footnotetext{
${ }^{147}$ Stocking, op. cit., note 16 above, p. xxx; Carlson and Dain, op. cit., note 6 above, p. 134.

148 Walker and McCabe refer the misinterpretation to Prichard's usage of the word "moral" with its varying ethical and psychological connotations. Their views were adopted by later scholars. Walker and MacCabe, op. cit., note 7 above, p. 208; Hunter and Macalpine, op. cit., note 10 above, p. 838; Smith, op. cit., note 6 above, p. 114 .
} 


\section{J C Prichard's Concept of Moral Insanity}

more often than not, of a moral rather than a physical kind. ${ }^{149}$ Moral insanity was Prichard's way of theorizing what appeared to him as the moral degeneracy of his age. Hence, it may be doubted that Prichard had all that much in common with alienists, such as Heinroth, who conflated immorality with disease, or with those such as Thomas Mayo, who suggested that workhouses should be introduced for disobedient children and other morally deficient individuals. ${ }^{150}$ An appropriate way to resolve this question is to look at the implications which moral insanity had for the mechanics of certification within Prichard's theory itself.

In the late $1820 \mathrm{~s}$, the practice of confinement had become highly controversial, culminating in a scandal which involved the well-known alienist George Man Burrows who had issued certificates without even personally inspecting the alleged patients. ${ }^{151}$ These events stirred up controversies about the validity of theories on madness. Part of the problem was the wide gap between the definition of insanity as it was accepted in the courts, and its actual exegesis in the practice of certification. Generally, only those criminals who displayed real hallucinations or illusions were passed as mentally unsound. But quite often people were subject to certification whose mental frame failed to display that sort of extreme mental aberration. ${ }^{152}$ One of the medical men who took up the issue was the young alienist John Conolly. In 1830, he published a treatise which strongly criticized contemporary abuses in the mad-business. Nowadays, Conolly is deemed the prototype of a medical reformer: young, radical-minded, at the fringe of the London establishment and an adherent of craniology as a useful instrument for mental pathology. ${ }^{153}$ One of the prime features in his Inquiry concerning the indications of insanity was his condemnation of the indiscriminate confinement of people who were merely eccentric or depraved. ${ }^{154}$

It has been shown that Prichard understood madness to be a necessary part of human nature. Moral insanity in particular constituted an extension of the definition of madness which makes - in theory-an infinitely greater number of people eligible for the diagnosis of madness than the traditional notion had allowed for. The question which must be raised in this context is whether moral insanity was meant to resolve the theoretical ambiguities around the practice of the mad-business in such a manner as to boost asylumdom. As will become clear, this was not so.

No less than Conolly, Prichard favoured confinement in all appropriate cases. Following Esquirol and the long tradition of British associationism, he thought that insane patients needed to be distracted from their usual surroundings, so that their minds could

149 Prichard, op. cit., note 2 above, p. 174.

$150 \mathrm{Cf}$. Thomas Mayo, An essay on the relation of the theory of morals to insanity, London, Fellowes, 1834.

151 This has been demonstrated in Akihito Suzuki's paper, 'The structure of the psychiatric bedside', given at the conference "'Voices from the past": source materials for the history of psychiatry' at the Wellcome Institute for the History of Medicine on 10 Feb. 1995.

152 Prichard himself was aware that given the unsatisfactory state of legal practice, expedience would occasionally overrule the law, see the case which he described in op. cit., note 123 above, pp. 226-7.

${ }^{153}$ Cf. Richard Hunter, Ida Macalpine, 'Introduction' to: John Conolly, An inquiry concerning the indications of insanity, London, Dawsons, 1964; Andrew Scull, 'A Victorian alienist: John Conolly, FRCP, DCL (1794-1866)', in Bynum, Porter, Shepherd (eds), op. cit., note 13 above, vol. 1, pp. 103-50.

154 John Conolly, An inquiry concerning the indications of insanity, with suggestions for the better protection and care of the insane, London, John Taylor, 1830. 


\section{Hannah F Augstein}

leave their morbid tracks of thought. ${ }^{155} \mathrm{He}$ endorsed a combination of the humane form of moral treatment and the traditional physical treatment of bleeding, purging, vomiting, etc. But in cases of moral insanity, Prichard assumed a very careful stance towards confinement. He acknowledged that it was difficult to come up with a clear-cut definition of lunacy for diagnosis. "The precise limitation of insanity and eccentricity of character is very difficult to discover," he wrote, and referred his readers to Conolly's book. ${ }^{156}$

One of Conolly's examples of an eccentric who should not be confined is a man whose only madness consists in his belief that his legs are made of butter. As long as they could somehow carry on in life, Conolly thought, men were free to think what they wanted, mad or not. ${ }^{157}$ As for Prichard, his typical borderline case was a morally insane individual whose awkward behaviour was due to deranged emotion. But, no less than Conolly, Prichard took it for granted that mere eccentricity of character was no reason for locking a person up. Even in cases of people who were so morally insane as to be unable to fulfil their civil responsibilities, Prichard did not suggest confinement. ${ }^{158} \mathrm{He}$ wrote:

There are probably many individuals who are wholly incompetent, through a habit of thoughtless extravagance resulting from disease, to administer their own estates, or manage their domestic affairs, and in whose condition there is yet nothing that requires confinement in a madhouse. ${ }^{159}$

It is, therefore, wrong to see Prichard as a man who was enthusiastic about confinement. In fact, he agreed with Conolly's exhortation for care in these matters. ${ }^{160}$

Prichard saw it as his duty to deal with the medico-legal side of madness. In 1842, he dedicated an entire book to the subject in which he covered both sides of the problem: criminality arising from insanity as well as the circumstances in which civil law could deal with insane behaviour. This dual perspective notwithstanding, his interest focused mainly on those aspects of insanity which came under civil rather than criminal law. ${ }^{161} \mathrm{He}$ stressed that the question of certification was a matter which could not be solved categorically.

The question which jurors will have to determine is, not whether the person whose case is under examination is afflicted with insanity according to any abstract definition, or general notion, as to the nature of that disease, but whether his mental state is individually such as to render him unfit to be at large, and to be entrusted with the care of himself and his property. ${ }^{162}$

Instead of deriving the criteria for certification from medical nosology, Prichard recommended that an alleged madman's social behaviour should be the criterion for his possible certification. This pragmatic advice originated with John Haslam. In 1817, after

\footnotetext{
155 Prichard, op. cit., note 2 above, p. 341.

156 Prichard, op. cit., note 2 above, p. 383; Conolly, op. cit., note 154 above, p. 173. Prichard had not always been a supporter of moral treatment, see his 'Remarks on the treatment of epilepsy and some other nervous diseases', Edinburgh med. J., 1815, 11: 458-66, p. 465.

157 Conolly, op. cit., note 154 above, pp. 136, 173.

158 Prichard, op. cit., note 2 above, pp. 23 ff, 45 .

159 Ibid., p. 402.

160 Prichard thought very highly indeed of Conolly. See his letter to the barrister Arthur James Jones
}

dated 24.7.1843, in Crossley papers, autograph collection, vol.3, Manchester Central Library.

161 This was due to the fact that murder was not a typical manifestation of moral insanity. It is notable that Prichard failed to give any attention to the famous trials which had agitated British discussion about forensic medicine since the turn of the century, and he was duly criticized for this. See [Anon.], 'Prichard, Winslow, \&c. on the plea of insanity in criminal cases', Br. for. med. Rev., 1843, 16: 81-110, p. 87.

162 Prichard, op. cit., note 123 above, p. 65. 


\section{J C Prichard's Concept of Moral Insanity}

he had ignominiously lost his post as apothecary to Bethlem hospital, Haslam had made the very same recommendation. ${ }^{163}$ In his case, his unorthodoxy might be seen as a response to his shameful experience. But Prichard's cautious attitude towards confinement fits perfectly with his views on human nature. He had interpreted the doctrine of predisposing causes in such a manner as to stipulate that the disposition to madness was part of universal human nature. The consequence was that every kind of peculiar behaviour was, for him, a sign of mental disorder. At least once, Prichard asserted that all eccentricity, however harmless it might appear, was a sign of madness. He wrote: "If . . . we are obliged to discuss the question, whether eccentricity is in general allied to madness, and even a modification of that state or not, there is no doubt that the decision would be in the affirmative". ${ }^{164}$ This statement is crucial. Nobody in Prichard's time would have doubted that eccentric behaviour was a very common feature in many individuals. Conolly, therefore, strove to negate the links between eccentricity and insanity; Prichard, by contrast, made them even stronger. The reason why he did not recommend treatment or certification to all individuals who were, in his understanding, mad is simply this: had this policy been implemented, a substantial part of the population would have had to be certified.

His personal attitude as a doctor sustains this interpretation. As a practitioner as well as in his capacity as a Commissioner in Lunacy, ${ }^{165}$ he exercised his duties with modesty, like a craft whose effectiveness was limited. He presented himself in his writings very differently from medical authors such as Burrows or Esquirol. He did not stress any special faculties of his own, comparable to Francis Willis's famous stare, nor did he give much credit to his role as a diagnosing specialist. Nor, for that matter, was he interested in the patients telling their stories. Rather, the diagnosis of moral insanity must rely on the testimony of people who had known the patient for some time, because one of the salient characteristics of the disorder consisted in a change of character.

\section{A Disease of the Rich}

This brings us to the social implications of moral insanity. When Prichard discussed the expediency of confinement, he said:

Confinement is unnecessary for such a person, who is in no way dangerous to society. If the management of his property-for such individuals are generally possessed of property-could be so settled as to ensure his having the usual supports of life, this would be sufficient. ${ }^{166}$

Buried in this sentence is a decisive aspect of moral insanity. It was usually a disorder of the affluent. And it was a disorder which was a lot more respectable than other ideas about unsoundness of mind. In a way, moral insanity served to create a class of patients who were not liable to be confounded with beastly imbeciles and the debilitated.

\footnotetext{
163 John Haslam, Medical jurisprudence as it relates to insanity, according to the law of England, London, C Hunter, 1817, p. 63.

164 Prichard, op. cit., note 5 above, p. 112.

165 For Prichard's role as a Commissioner in Lunacy see Nicholas Hervey, 'A slavish bowing
}

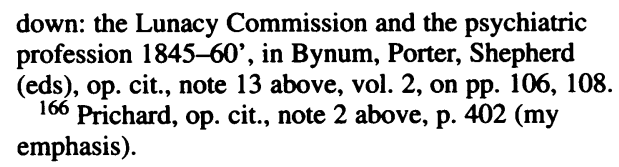

down: the Lunacy Commission and the psychiatric profession 1845-60', in Bynum, Porter, Shepherd (eds), op. cit., note 13 above, vol. 2, on pp. 106, 108.

166 Prichard, op. cit., note 2 above, p. 402 (my emphasis). 


\section{Hannah F Augstein}

The notion of a civil disease for the upper strata of society can be seen as linking up with Prichard's hesitation to recommend confinement: it all pandered to the attitudes of an educated class of possible clients. Asylums had in those days a poor reputation with the general public, ${ }^{167}$ and it was very much in the interest of an alienist to play down the importance of confinement. Hence Prichard's claim that in some forms of moral insanity it was sufficient to take the management of his property out of the hands of the disturbed individual. To see moral insanity in this manner, as a polite form of madness, was a concomitant of Prichard's assumption that the disorder was characteristic of civilization. Brute men-savages as well as peasant folk-were not refined enough for the "cold egotism" which held sway in modern life and which was to a large extent responsible for the rising numbers of madmen. Also, the particular type of anxieties modern men suffered from, loss of fortune or professional ambition, were not to be found in primitive societies. Prichard commented:

The apparent increase is everywhere so striking, that it leaves on the mind a strong suspicion ... that cases of insanity are far more numerous than formerly. ... It is encouraged by the reflexion that the state of society is, in most countries, such as appears likely to multiply the exciting causes of madness. . . . Sufficient evidence has arisen to confirm in a great measure the remark made, many years ago by $M$. Esquirol, that insanity belongs almost exclusively to civilized races of men: it scarcely exists among savages, and is rare in barbarous countries. ${ }^{168}$

What applied to insanity broadly speaking and to different stages of civilization, was true for moral insanity as well. Given that Prichard considered all his contemporaries to be liable to moral insanity, he logically assumed that the "more civilized" strata of society were more endangered than the lower classes. The aetiology of moral insanity covered many symptoms which were not dependent on social status. Yet there was an old tradition which regarded the refined classes as more susceptible to feeling than the ordinary strata of society. Moral insanity, defined as a disease of the passions, was therefore especially prevalent among refined and propertied people.

With moral insanity, Prichard devised a model disease which explained in psychiatric terms the despicable moral corruption of his times and, in particular, of the affluent, who had the means to indulge in "moral debasement" until they were mad. Paradoxically, this very aspect of the disease was apt to make it more palatable to the public. The creation of

\footnotetext{
167 Two parliamentary inquiries and the subsequent popularizations of their findings could not fail to make the public wary of malpractice in the asylums. See, for example, Andrew Scull, The most solitary of afflictions, note 9 above, pp. 115-46; see also Peter McCandless, 'Liberty and lunacy: the Victorians and wrongful confinement', in Andrew Scull (ed.), Madhouses, mad-doctors and madmen: the social history of psychiatry in the Victorian era, Philadelphia, University of Pennsylvania Press, 1981.

168 Prichard, op. cit., note 2 above, p. 350, see also p. 175 where Prichard discusses the truth of this hypothesis. Esquirol frequently suggested that madness was a typical disease of civilization, see, e.g., Esquirol, Des passions, considérées comme causes, symptômes et moyens curatifs de l'aliénation
}

mentale, Paris, Didot Jeune, an XIV (1805), in Collection des thèses, Paris, 1805 , no. 574, p. 15. As to historiographical accounts of the dangers of civilization see Mark D Altschule, 'The concept of civilization as a social evil in the writings of midnineteenth-century psychiatrists', in idem, Essays in the history of psychiatry, 2nd rev. ed., New York, London, Grune \& Stratton, 1965; Jean-Christophe Coffin, 'Is modern civilization sick? The response of alienists in mid-nineteenth-century France', in Leonie de Goei, Joost Vijselaar (eds), Proceedings of the 1st European Congress on the History of Psychiatry and Mental Health Care, Rotterdam, Erasmus, 1993; Andrew Scull, 'Was insanity increasing?' in idem, Social order/mental disorder, op. cit., note 9 above. 


\section{J C Prichard's Concept of Moral Insanity}

the concept could be called a cunning selling strategy, except that its formulation was a result of Prichard's views on human nature and his despair at the moral depravation of his time.

In addition to this link between moral insanity and the affluent classes, there is another respect in which the consideration of property was pivotal in Prichard's thought. Prichard put forward his pleas for confinement in certain cases, first of all, in the name of social order: "Of all these arrangements the maintenance of public order is the principal object, and the second is the preservation of the property belonging to the lunatic and the interest of his family." 169 It is notable that Prichard's concern circled around notions of property and the avoidance of social upheaval. Esquirol, by contrast, had put much greater emphasis on propriety. ${ }^{170}$ Esquirol's theory was suitable for post-revolutionary French society where the aristocracy as well as the high bourgeoisie tried to re-establish distinct social hierarchies. For him, much more than for Prichard, nymphomania and satyriasis were diseases concomitant with civil society. ${ }^{171}$ Property was not one of the topics which specially preoccupied Esquirol. For Prichard, however, it was not social hierarchy but the preservation of peace and order which was at the centre of his concern. Legal interference was needed when a mentally disturbed person threatened to harm himself, other people or their property. Society had not only the right, but the duty to interfere with persons who, like Symonds's gentleman patient, squandered their possessions and threatened to throw their families into poverty. ${ }^{172}$

Insanity was, for Prichard, a prevalent menace. It was not an exceptional misfortune, but rather a predicament society had to live with. All eccentric behaviour was indicative of a deranged mind. It was impossible to get rid of the affliction altogether, and since many eccentrics did no harm to anybody, their behaviour could be tolerated. But for the sake of social cohesion society had to defend itself when its law and order were attacked. This is why Prichard chose the preservation of social order, of property and personal safety, as the criteria for certification.

\section{Conclusion}

Moral insanity arose primarily out of Prichard's theological interest in sustaining the doctrine of the immaterial soul. The concept was expressive of his views on the precarious morality of modern man rather than of his desire to draw definite dividing lines between the sound and the unsound. For Prichard, man's mental health was ultimately tied to his religion. He was a medical dualist who thought that medicine could not do much for the mind. ${ }^{173}$ In so far as madness was a physical disease medicine could cure it; if that failed it could aid the law in preserving the social order.

\footnotetext{
169 Prichard, op. cit., note 5 above, p. 135.

170 Henriques has shown that property was the rationale for British restoration ideology. See Ursula R Q Henriques, Before the welfare state: social administration in early industrial Britain, London, New York, Longman, 1979.

171 In his doctoral thesis, Esquirol explained in physiological terms why the sexual passions were so particularly delicate, see Esquirol, op. cit., note 168 above, p.12.
}

\footnotetext{
172 Exaggerated thrift and "the propensity to make extravagant purchases" were only two among a wide range of symptoms of moral insanity. None the less, they play an important role in Prichard's aetiology. See Prichard, op. cit., note 123 above, p. 2; idem, op. cit., note 5 above, p. 112 (his emphasis).

${ }^{173}$ For a discussion of Prichard's dualism see my PhD thesis, op. cit., note 45 above.
} 
Ironically, the course of events took a direction which was directly opposed to Prichard's designs. His zealous endeavour to sustain the doctrine of the soul against contemporary forms of medical materialism inadvertently supported another form of secularization of the mind. Prichard had referred the mechanisms of psychology to the body in order to preserve the soul's untainted immateriality. In the second half of the nineteenth century, as Michael Clark has shown, alienists would enlarge upon ideas which formed the physicalist part of the Prichardian anthropology. ${ }^{174}$ The notion of atonement, however, which included the whole of humanity, was lost. While Prichard had fought phrenology, his successors were to combine it with moral insanity. In the later decades of the nineteenth century, theories about hereditary mental degeneration were spreading. Accordingly, men were doomed by birth, not metaphysically but in terms of their physical heritage. How easily these notions could be combined with moral insanity is exemplified in the articles of John Kitching. In the 1850s, Kitching served as the medical superintendent of the York Retreat. In his contributions to the British Medical Journal he applied doctrines of phrenology and hereditary degeneration to the concept of moral insanity. Madness was for him solely a question of "disordered functions of the brain". Moral insanity was the "arrested development in those parts of the brain, which are concerned in the due performance of the moral and instinctive faculties". ${ }^{175}$

In legal practice, by contrast, moral insanity failed to become an accepted category. Prichard's attempt to help the legal enforcement of morality proved fruitless. The McNaughton rules of 1842 confirmed the persistence of the orthodox definition of madness which presupposed outright delusion. ${ }^{176}$ In the end, Prichard's endeavours were stifled. British law did not acknowledge moral insanity as he had hoped. Victorian alienists misinterpreted it. ${ }^{177}$ While Prichard had managed to hold a careful balance between the organic sources of the disease and its effects on man's morality on the one hand, and the organic implications of man's metaphysical framework on the other hand, subsequent generations confined moral insanity and its implications entirely to the physical sphere. Moral insanity, Prichard's legacy to medical psychiatry, was employed in

\footnotetext{
174 Michael Clark, “"Morbid introspection”, unsoundness of mind, and British psychological medicine, c. 1830-1900', in Bynum, Porter, Shepherd (eds), op. cit., note 13 above, vol. 3.

175 John Kitching, 'Lecture on moral insanity', $B$ r. med. J., 1857, i: 334-6, 389-91, 453-6. For notions of degeneracy in British psychiatry see Janet Saunders, 'Quarantining the weak-minded: psychiatric definitions of degeneracy and the lateVictorian asylum', in Bynum, Porter, Shepherd (eds), op. cit., note 13 above, vol. 3. For theories on degeneration in general see Peter Burgener, Die Einflüsse des zeitgenössischen Denkens in Morels Begriff der "dégénérescence", Zurich, Juris-Verlag, 1964; Rafael Huertas, 'Madness and degeneration, III. Degeneration and criminality', Hist. Psychiatry, 1993, 4: 141-58; idem, 'Madness and degeneration, IV. The man of genius', ibid., pp. 301-19; Daniel Pick, Faces of degeneration. A European disorder, c. 1848-c. 1918, Cambridge University Press, 1989.

176 Eigen has shown that the attempts of consulting alienists to introduce the concept of moral insanity in
}

the courtroom were on the whole unsuccessful; Eigen, op. cit., note 6 above, pp.149-52. According to Smith, "the terms impulsive and moral insanity ... were rarely helpful to the defence strategy"; Smith, op. cit., note 6 above, p. 123. With regard to the preservation of property, however, the English legal system did indeed take action: the Lunacy Regulation Act of 1853 strengthened the system whereby relatives or heirs of a propertied person could petition the Lord Chancellor to have the state take over the stewardship of the estate. The individuals found insane under this procedure were termed "chancery lunatics", see ibid., p. 69.

${ }^{177}$ Cf., e.g., W B Carpenter, Principles of mental physiology, 3rd ed., London, Kegan Paul, Trench, 1888 (1874); Henry Maudsley, Responsibility in mental disease, London, Harry S King, 1874; idem, The pathology of mind. A study of its distempers, deformities and disorders, ed. Sir Aubrey Lewis, London, Julian Friedman, 1979; Forbes Winslow, The plea of insanity in criminal cases, London, H Renshaw, 1843. 


\section{J C Prichard's Concept of Moral Insanity}

conceptualizations of madness which overrode the transcendental nature of man. References to the soul were to become at best the philosophical superstructure in the belief systems of individual alienists. But on the whole metaphysics were severed from medical theories-a development which would have confirmed Prichard's worst misgivings, had he lived to witness it. 